\title{
The Role of Southwesterly Flow in MCS Formation During a Heavy Rain Event in Taiwan on 12 - 13 June 2005
}

\author{
Fang-Ching Chien * \\ Department of Earth Sciences, National Taiwan Normal University, Taipei, Taiwan, R.O.C.
}

Received 29 July 2014, revised 11 November 2014, accepted 11 March 2015

\begin{abstract}
This paper presents a numerical study of a heavy rain event that occurred in southern Taiwan in June 2005. From 11 - 13 June 2005, a weak Mei-yu front moved southeastward from China to Taiwan, while mesoscale convective systems (MCSs) were developing and moving northward over the northern South China Sea (SCS). During the first day of the event the southwesterly flow intensified when a ridge associated with the Pacific high extended northwestward from the Philippines to the southern Taiwan Strait (TS). This pressure pattern produced a large northwestward pressure gradient force that created a southeasterly wind speed increase followed by intensification of the southwesterly flow through Coriolis acceleration. An low-level jet (LLJ) formed consequently and transported moisture and unstable air toward the southwestern coast of Taiwan. MCSs were triggered in the southwesterly flow because the potentially unstable air was lifted in a low-level convergence and shearing vorticity environment. They intensified, became organized, and moved northeastward overland, resulting in heavy rainfall in southern Taiwan. On the second day, low pressure formed near the southern TS because of the combined effect of a travelling short-wave trough and a pressure reduction resulting from the latent heat release by the evolving MCSs. This pressure change produced down-gradient acceleration in the northeastward direction, resulting in southwesterly flow strengthening. The local wind acceleration was smaller than that of the first day because the dominant pressure system was local scale, while that of the first day was synoptic scale.
\end{abstract}

Key words: Mei-yu front, Heavy rain, Low-level jet, Southwesterly flow

Citation: Chien, F.C., 2015: The role of southwesterly flow in MCS formation during a heavy rain event in Taiwan on 12 - 13 June 2005. Terr. Atmos. Ocean. Sci., 26, 411-429, doi: 10.3319/TAO.2015.03.11.01(A)

\section{INTRODUCTION}

Taiwan is one region of the world that is frequently affected by heavy precipitation. The island has a complex, high-altitude terrain that consists of steep mountain ranges with peaks exceeding $3000 \mathrm{~m}$, such as the Central Mountain Range (CMR). The CMR is often a major factor in extreme rainfall events because it can modify the airflow and provide extra forcing to the existing weather system convection. During a Mei-yu (plum rain) season, which usually occurs from mid-May to mid-June, quasi-stationary fronts (or Mei-yu fronts) frequently form over southeastern China and move toward the Taiwan area, resulting in extended periods of precipitation (e.g., Chen 1983; Tao and Chen 1987; Ding 1992). Since the Taiwan Area Mesoscale Experiment was conducted (TAMEX; Kuo and Chen 1990), many stud-

\footnotetext{
* Corresponding author

E-mail:jfj@ntnu.edu.tw
}

ies have been performed to improve the understanding of weather systems associated with Mei-yu fronts (e.g., Chen and Hui 1990; Ray et al. 1991; Chen and Liang 1992; Lin et al. 1992; Li et al. 1997).

A Mei-yu front usually appears on satellite images as an elongated cloud band extending from Japan to southern China (Chen 2004). Long-lived mesoscale convective systems (MCSs) are often embedded within the cloud band that bring heavy rain and flash floods to the region (e.g., Lau et al. 1988; Kuo and Chen 1990; Zhang et al. 2003). A low-level jet (LLJ) is frequently observed south of the front and plays an important role in transporting warm and moist air from the tropical ocean to the frontal zone (Chen and Yu 1988; Li et al. 1997; Chen et al. 2005). Chen and Chen (1995) attributed the formation of many LLJs to lee-trough formation and geostrophic adjustment occurring east of the Tibetan Plateau. Other studies suggested that heavy rain along the 
front could induce strong secondary circulation. LLJs could form south of the rain area through a Coriolis torque on the northward moving lower branch of the secondary circulation (e.g., Chou et al. 1990; Nagata and Ogura 1991; Chen et al. 1998). Kato (1998) numerically studied a torrential rain event in Japan and found that the LLJ was very important in transporting moist air into the rainfall region and its formation was primarily contributed by the pressure gradient force resulting from the convection-induced low. Chen et al. (2006) documented that the frontal MCSs induced a localized LLJ through latent heating, and the jet, in turn, led to the northward retreat of the nearby front. Since winds are usually blowing from southwest toward northeast equatorward of a Mei-yu front, southwesterly flow is often used by the Taiwanese meteorology community to describe such an environment in a more general manner. However, the existence of southwesterly flow does not necessarily guarantee an LLJ. The wind speeds have to be stronger than $15 \mathrm{~m} \mathrm{~s}^{-1}$ at low level (e.g., $850 \mathrm{hPa}$ ) and decrease both upward and downward to identify an LLJ (Chen et al. 2005).

The synoptic structure of the Mei-yu front, typically different from that of a mid-latitude front, is characterized by a weak temperature gradient, but with a strong moisture contrast and a high equivalent potential temperature gradient (Ding 1992). In addition, the Mei-yu front signatures in the lower troposphere $(900-700 \mathrm{hPa})$ are more pronounced in the wind field than in the thermal field. The front is usually very shallow (generally less than $1 \mathrm{~km}$ deep) and slopes rapidly with height, with a low-level cyclonic wind shear line located about 200 - $300 \mathrm{~km}$ north of the surface front (Chen et al. 1989; Trier et al. 1990). The thermodynamic stratification around Taiwan under the influence of a Mei-yu front is often conditionally unstable within the warm, moist southwesterly monsoon flow (Chen and Chen 2003). With a combination of abundant moisture, low-midlevel wind shear, and conditional instability in the southwest monsoon, the atmosphere often favors the formation of organized MCSs (Lin et al. 1990; Wang et al. 1990). Heavy rainfall is most common on the west side of the CMR because of the interaction of synoptic and sub-synoptic weather systems with the Taiwan terrain ( $\mathrm{Li}$ et al. 1997; Teng et al. 2000; Chen et al. 2007). Such orographic precipitation enhancement is also documented for many other mountain ranges over the world (e.g., Colle et al. 2008; Smith et al. 2010).

Although many studies regarding Mei-yu fronts have been performed in the past, few have examined the formation and development of the southwesterly flow and its relationship with MCSs and heavy rain in southern Taiwan. In June 2005, a heavy rain event occurred in southern Taiwan from 11 - 13 June, with daily precipitation exceeding $300 \mathrm{~mm}$ at many stations. The torrential rain caused flooding and mudslides in mountainous regions. This storm system was closely related to the influence of a Mei-yu front and the intensification process of the southwesterly flow. The purpose of the current paper is to investigate this heavy rain event by proposing the following scientific goals: (1) to examine the causes of the heavy rain, (2) to investigate the evolution of the southwesterly flow and the factors that play a role in southwesterly flow intensification, and (3) to study the relationship between the strengthening southwesterly flow and MCS development.

\section{DESCRIPTION OF THE EVENT}

The surface weather maps issued by the Central Weather Bureau (CWB) show that at 0000 UTC 11 June 2005 (Fig. 1a), a low pressure center of $994 \mathrm{hPa}$ was located over southern Japan. A Mei-yu front extended southwestward from the low center to southeastern China. By 0000 UTC 12 June 2005 (not shown), the Mei-yu front had moved southward over the Taiwan area and remained nearly stationary for the next four days (see frontal location at 0000 UTC 13 June in Fig. 1b). Although it is not uncommon for a Mei-yu front to affect Taiwan for several days, the 5-day continuous presence of this front near the Taiwan area made it a rare event. Figures $1 \mathrm{a}$ and $\mathrm{b}$ show that the Pacific subtropical high extended southwestward over the Pacific, causing southwesterly flow strengthening over the northern SCS. The surface wind speed increased from weak wind to $\sim 10 \mathrm{~m} \mathrm{~s}^{-1}$ within 2 days.

The 850-hPa geopotential height and wind analyses from the National Centers for Environmental Prediction (NCEP) global final analysis system (FNL) show that at 1200 UTC 11 June 2005 strong southwesterly winds $\left(\geq 10 \mathrm{~m} \mathrm{~s}^{-1}\right)$ extended northeastward from the South China Sea (hereafter, SCS) and the Luzon Strait to the southeast of the low center near Japan (Fig. 2a). Another area of strong winds was observed over the Bay of Bengal, and it spread toward the Indo-China Peninsula. One day later at 1200 UTC 12 June 2005 (Fig. 2b), the Pacific subtropical high strengthened and extended east of the Philippines and the two areas of strong winds connected together over the northern SCS. The southwesterly flow zone thus extended from the Bay of Bengal all the way toward east of Japan. It also shifted northwestward over the southern Taiwan Strait (hereafter, TS) and southern Taiwan, with the associated winds strengthening greatly to the south and east of Taiwan. At 1200 UTC 13 June 2005 (Fig. 2c) the southwesterly flow over the southern TS and the northern SCS further intensified.

Sounding observations at Tongsha Island (located about $400 \mathrm{~km}$ southwest of Taiwan, see Fig. 3b for location) show that at 0000 UTC 13 June, strong southwesterly winds exceeded $15 \mathrm{~m} \mathrm{~s}^{-1}$ at $950-850 \mathrm{hPa}$, suggesting the existence of an LLJ (Fig. 4). The low-level air during this period was moist and conditionally unstable. The lifting condensation level (LCL) was just above the surface $(990 \mathrm{hPa})$ and the level of free convection (LFC) was also very low $(947 \mathrm{hPa})$. With a high equivalent level (EL), the area of positive energy 
(a)

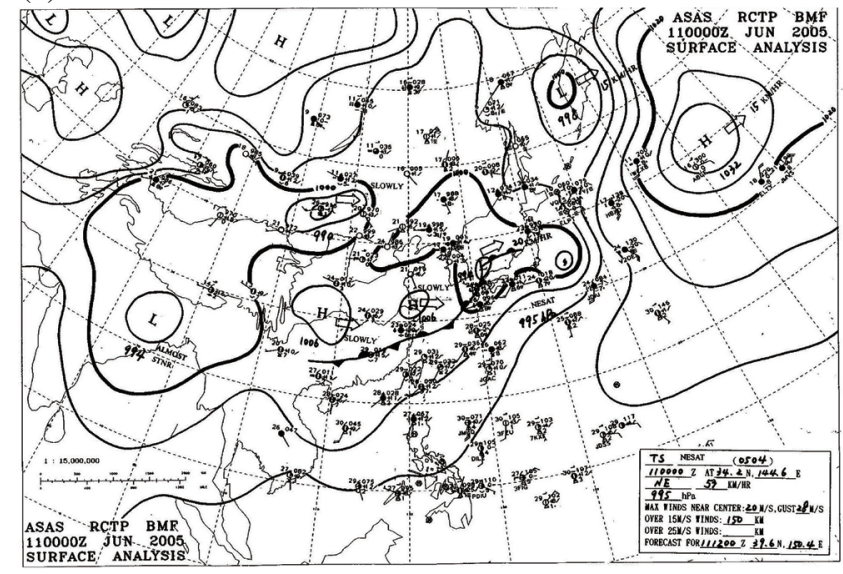

(b)

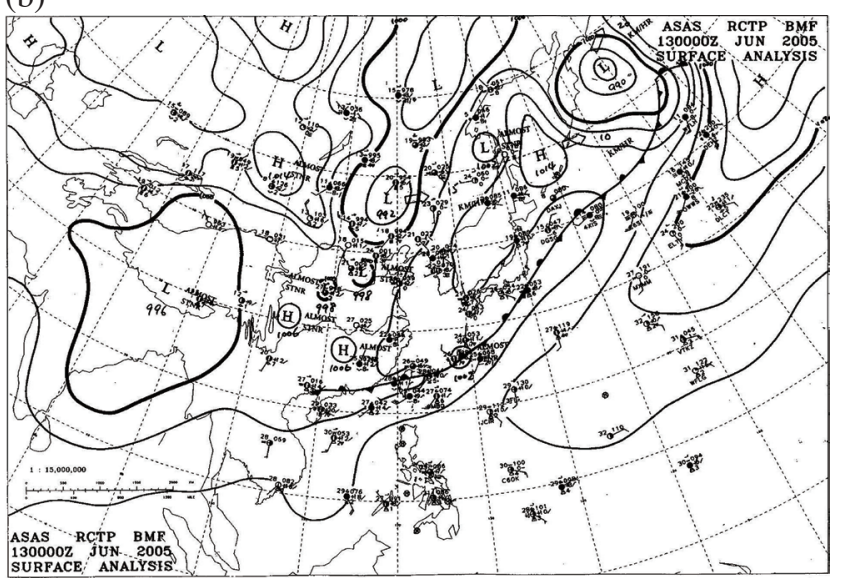

Fig. 1. Surface weather maps issued by the Central Weather Bureau (CWB) at (a) 0000 UTC 11 June 2005, and (b) 0000 UTC 13 June 2005. Contour interval for sea level pressure is $4 \mathrm{hPa}$.
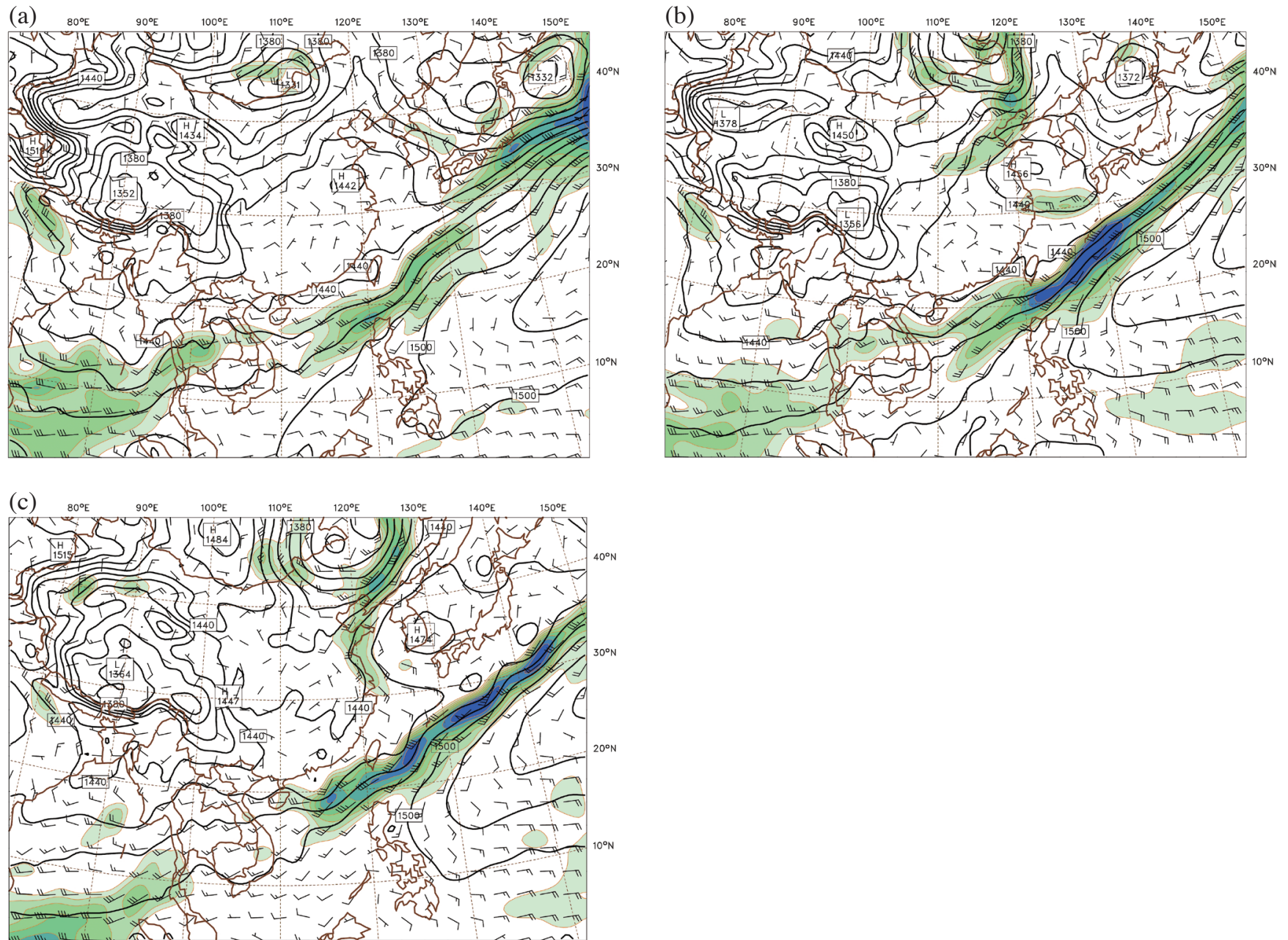

Fig. 2. The 850-hPa geopotential height (solid lines with a $15-\mathrm{m}$ interval), wind barbs (full bar: $5 \mathrm{~m} \mathrm{~s}^{-1}$ ), and wind speed (color shading with red lines, starting at $10 \mathrm{~m} \mathrm{~s}^{-1}$ with a 2-m s${ }^{-1}$ interval) from the NCEP final analysis (FNL) data at (a) 1200 UTC 11 June 2005, (b) 1200 UTC 12 June 2005, and (c) 1200 UTC 13 June 2005. 

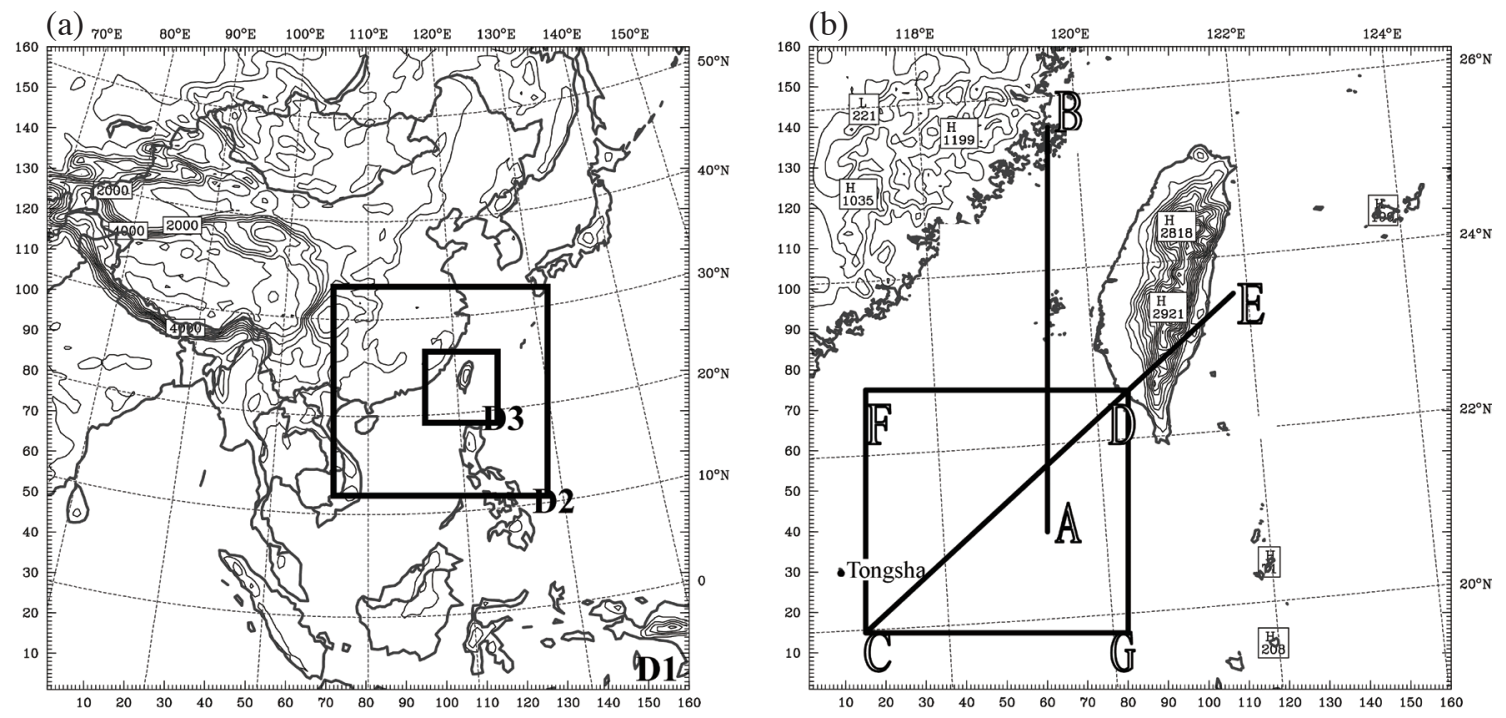

Fig. 3. The domain setting of model simulation. (a) Horizontal resolution of domains 1,2 , and 3 are 45,15 , and $5 \mathrm{~km}$, respectively. Terrain height is plotted with a 500-m interval. (b) Terrain height of domain 3 is plotted with a 200-m interval. Lines AB, CD, and CE denote the locations of cross sections. Box CFDG represents the area of domain average.

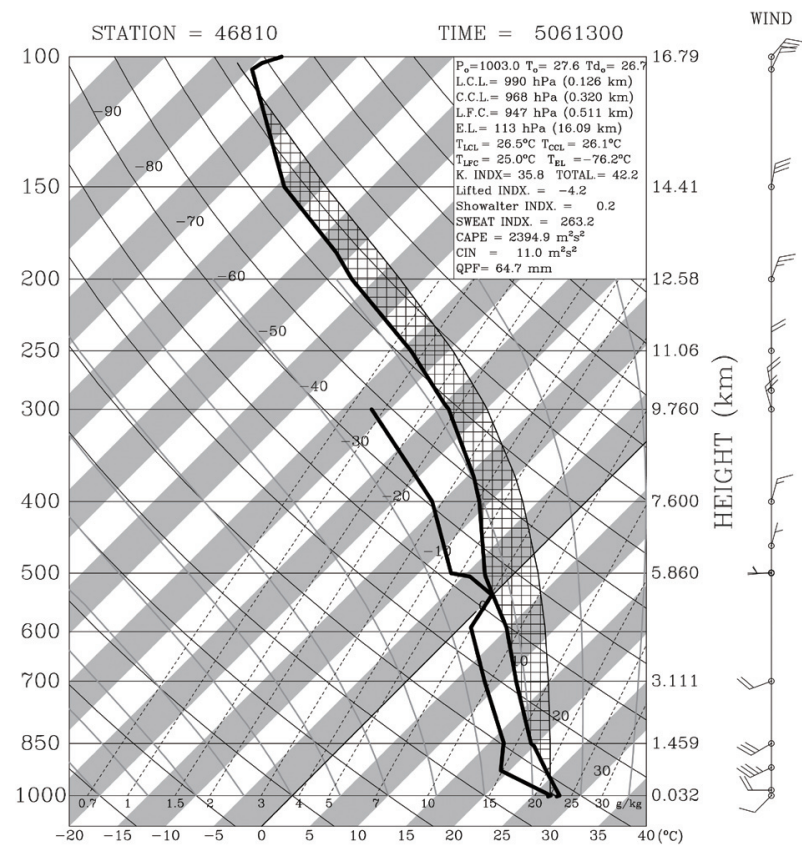

Fig. 4. Skew-T log P diagrams at Tongsha station at 0000 UTC 13 June 2005. Hatched regions indicate the area of positive energy. Some commonlyused parameters associated with sounding are calculated and shown in upper right.

(hatched region) was quite large, indicating high convective available potential energy (CAPE, $\sim 2400 \mathrm{~m}^{2} \mathrm{~s}^{-2}$ ) at this time.

Figure 5 presents the brightness temperature and QuikSCAT surface winds around the Taiwan area. On 11 June (Fig. 5a), while the weak Mei-yu front associated with MCSs A and B was moving slowly southeastward from southeastern China toward Taiwan, MCSs C and D were developing and moving northward in the southwesterly flow environment over the SCS. MCS C made landfall at
2200 UTC 11 June and brought rainfall in southern Taiwan (Fig. 5b). Radar reflectivity at 0200 UTC 12 June (Fig. 6a) showed strong convection in southern Taiwan in association with MCS C. MCS D was located farther to the south. By 0400 UTC 12 June, the Mei-yu front had arrived at northern Taiwan and MCS B had dissipated (Fig. 5c). To the south of Taiwan, many small MCSs developed and dissipated one after another such that it is difficult to give each one a unique identification. MCSs C and D are thus used to identify these 
regions of active convection. These MCSs developed and moved toward southern Taiwan at 0500 - 0800 UTC 12 June (Fig. 6a). By 1000 UTC 12 June (Fig. 5d), the front was associated with strong wind shear and an elongated cloud band that extended southwestward from southern Japan to eastern Taiwan. However, the front to the west of Taiwan was relatively difficult to identify because it had become a broad zone of convection, associated with low pressure and weak windshifts over the TS. More MCSs (C and D) developed over the northern SCS as a result of the strengthening southwesterly flow.

At 1100 UTC 12 June, an east-west oriented convective band (denoted by $\mathrm{Y}$ ) formed in the broad region of weak frontal environment near the central TS (Fig. 6a). This convective band was associated with weak radar reflectivity and no associated high cloud was observed at this time (see
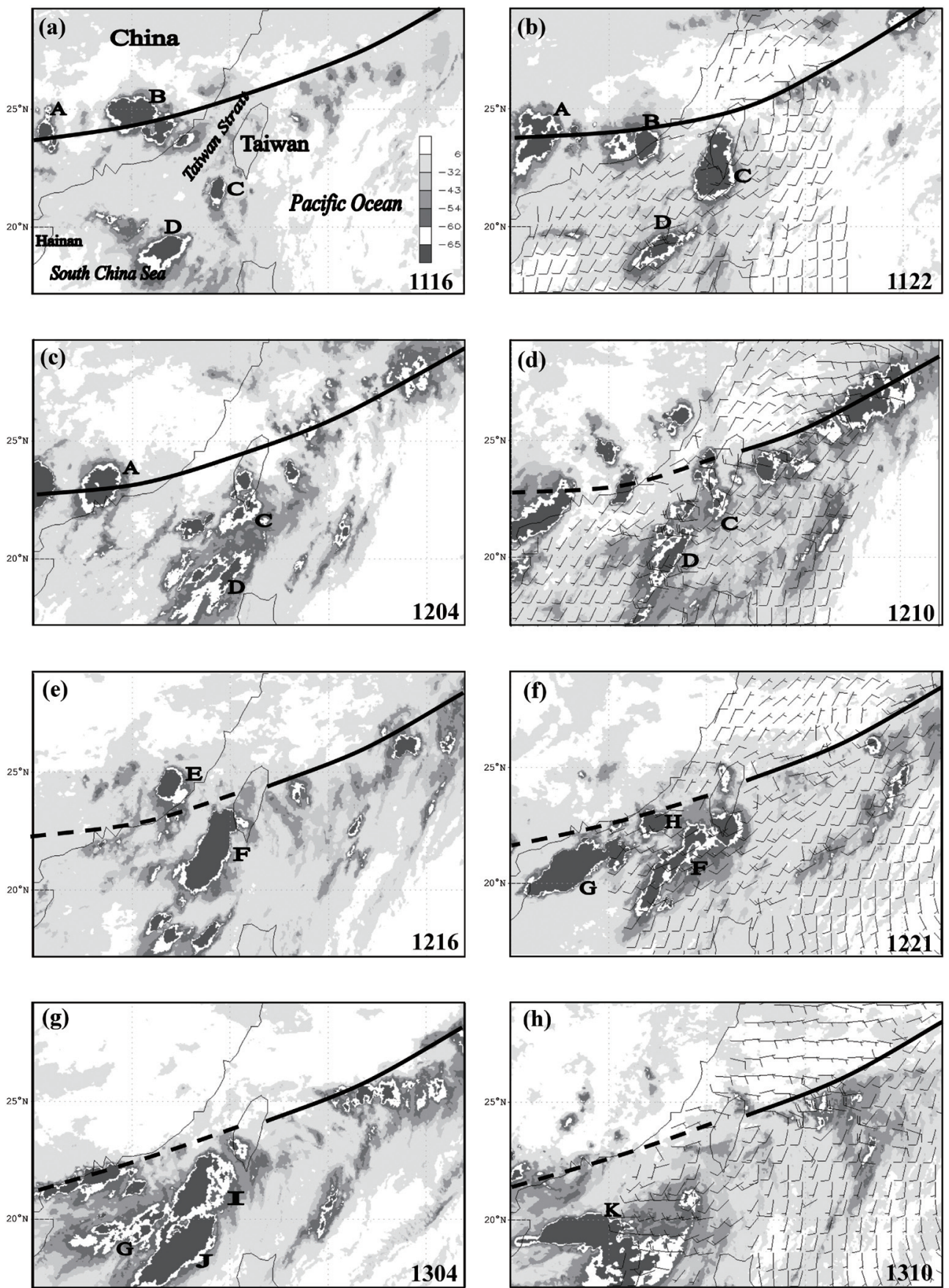

Fig. 5. Infrared satellite brightness temperature (shading) and QuikSCAT surface wind (full barb is $5 \mathrm{~m} \mathrm{~s}^{-1}$ ) at (a) 1600 UTC 11 June, (b) 2200 UTC 11 June, (c) 0400 UTC 12 June, (d) 1000 UTC 12 June, (e) 1600 UTC 12 June, (f) 2100 UTC 12 June, (g) 0400 UTC 13 June, and (h) 1000 UTC 13 June 2005. The thick line indicates the location of a front, with dashed line denoting a weak or insignificant front. MCSs are denoted by letters A - K. 
(a)

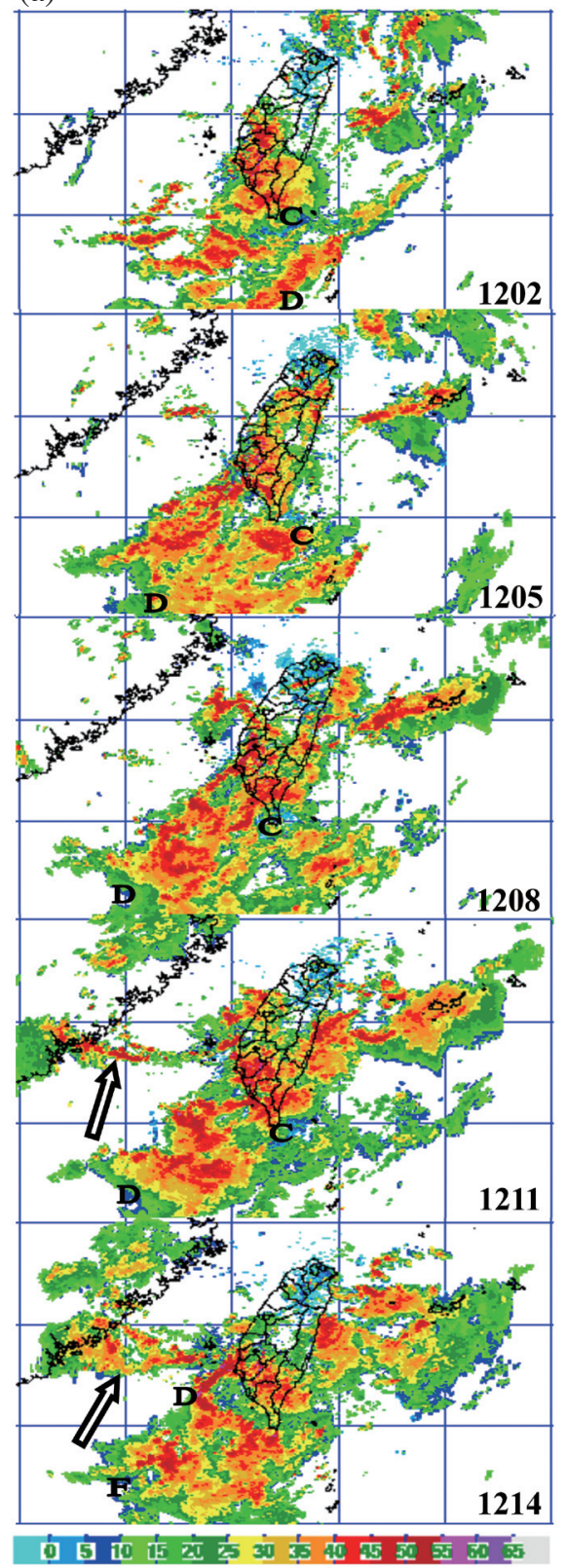

(b)

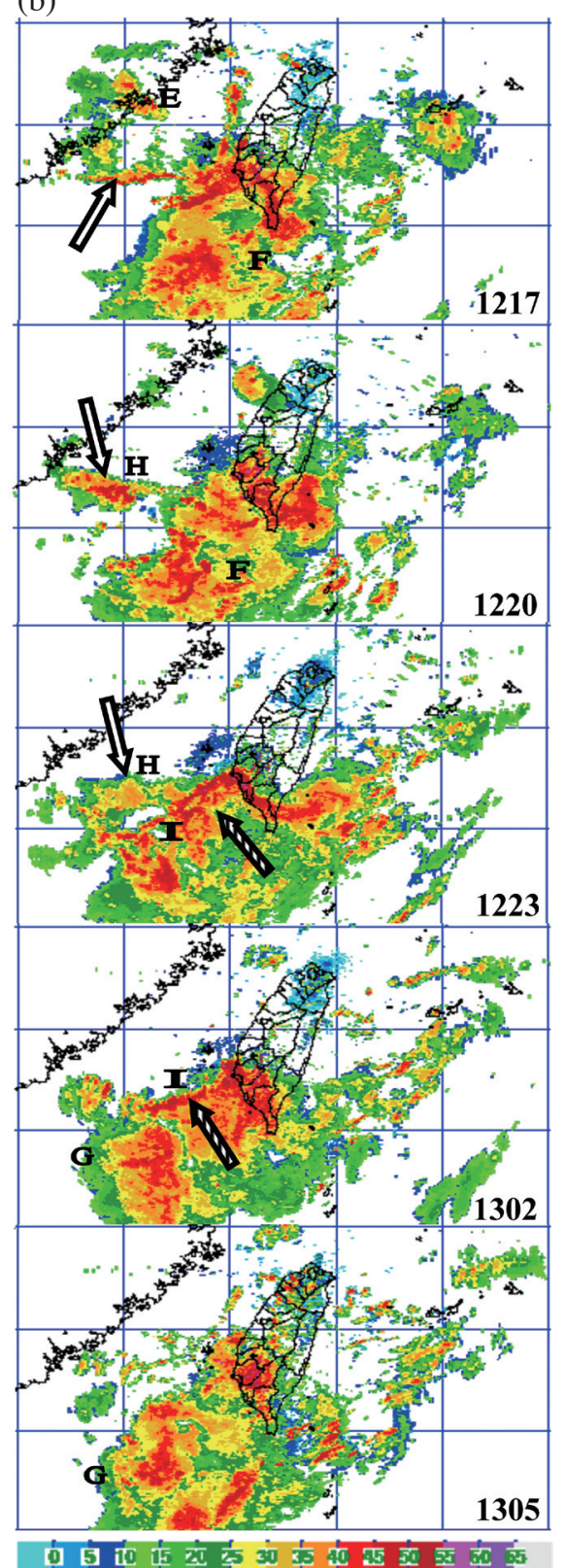

Fig. 6. Radar reflectivity images (dBZ, with scale shown on the bottom) (a) from 0200 UTC 12 to 1400 UTC 12 June 2005 , and (b) from 1700 UTC 12 to 0500 UTC 13 June 2005 at a 3-h interval. Convective bands Y and Z are indicated by hollow and hatched arrows, respectively. MCSs corresponding to Fig. 5 are denoted by upper-case letters.

Fig. 5d). At 1600 UTC 12 June (Fig. 5e), MCS E formed in the broad frontal zone and the small MCSs to the southwest of Taiwan organized into a larger MCS F. The aforementioned convective band $\mathrm{Y}$ intensified and moved southward from 1400 UTC to 2000 UTC 12 June (Figs. 6a, b), and it was associated with deep clouds at 2100 UTC 12 June (see MCS H in Fig. 5f). By this time, MCS F had brought heavy rainfall to southern Taiwan and then weakened (Fig. 5f). In the upstream area the southwesterly flow further strengthened, with many MCSs ( $\mathrm{G}$ and $\mathrm{H})$ triggered. At 2300 UTC 12 June 2005 (Fig. 6b), the convective band Y weakened and moved over the ocean southwest of Taiwan. To its south another band of intense convection associated with MCS I formed and extended from the ocean toward the southwestern coast. At 0200 UTC 13 June, this convective band (denoted by Z) intensified and moved overland with its associated MCS I, producing heavy rainfall in southern Taiwan. The evolving MCS I can also be identified from the satellite image at 0400 UTC 13 June (Fig. $5 \mathrm{~g}$ ). After that the convection started to dissipate at 0500 UTC 13 June (Fig. 6b). By 1000 UTC 13 June, the convection in southern Taiwan had nearly come to an end (Fig. 5h). Only remnants of MCSs 
(denoted by K) were found over the SCS, with southwesterly winds turning into westerly winds.

After the aforementioned MCSs over the southern TS and the northern SCS moved overland, they were further enhanced on the mountain slopes in southern Taiwan on 12 and 13 June 2005, resulting in heavy rainfall. As shown in the 24-h accumulated rainfall from 1200 UTC 11 to 1200 UTC 12 June (Fig. 7a), heavy rain ( $\geq 100 \mathrm{~mm}$ ) was observed from central to southern Taiwan, especially on the southwestern part of the island. The maximum precipitation of $400 \mathrm{~mm}$ occurred over the mountainous regions in southern Taiwan. In northern and eastern Taiwan, only light rain $(\leq 40 \mathrm{~mm})$ was observed. On the next day (Fig. 7b), heavy rain still occurred in southwestern Taiwan, with a maximum reaching $430 \mathrm{~mm}$. In summary, heavy rain in southern Taiwan was caused by the MCSs over the southern TS and the northern SCS that moved overland at a later time. The aim of this paper is therefore, through numerical simulation, to investigate the factors that are favorable for MCS formation.

\section{THE MODEL SIMULATION}

The Weather Research and Forecasting (WRF) model version 3.1.3 was used for numerical simulation. The numerical results were applied to examine the detailed structure and evolution of the MCSs and southwesterly flow, and to perform the momentum budget analysis.

\subsection{The Model Design and the Simulated Rainfall}

The WRF domain settings include 3 domains with 45-, 15-, and 5-km horizontal resolutions and 44 sigma levels in the vertical. Each domain has 160 by 160 grid points. The model top is at $50 \mathrm{hPa}$ and the lowest level is at approximately $30 \mathrm{~m}$ above ground level (AGL). Figure 3 shows the locations of the 3 nested domains and the terrain height of domain 3. The physics processes applied in the simulation include the WRF single-moment 5-class microphysics (Hong et al. 2004), the Kain-Fritsch cumulus parameterization (only applied in domains 1 and 2; Kain and Fritsch 1993), and the Yonsei University (YSU) planetary boundary layer (PBL) schemes (Hong et al. 2006). The model was initialized at 1200 UTC 11 June 2005 and ran for $60 \mathrm{~h}$. The initial and boundary conditions were obtained from the NCEP FNL analysis data with a horizontal resolution of one degree.

The simulated rainfall at $0-24 \mathrm{~h}$ shows two maxima of 501 and $410 \mathrm{~mm}$ over southern Taiwan in the finest grid $(5 \mathrm{~km})$ of the model simulation (Fig. 7c). Compared with the observed rainfall during the same time period (Fig. 7a), the WRF model reproduced the heavy rainfall well in southern Taiwan, but produced too much rainfall over central and eastern Taiwan. At 24 - 48 h (Fig. 7d) the model still produced heavy rainfall in southern Taiwan, except that the maximum rain was slightly less than that in the observation
(Fig. 7b). In summary, the WRF model did not reproduce rainfall amounts and locations perfectly, but it did capture the overall heavy rainfall pattern in southern Taiwan.

\subsection{MCSs and the Causes of Heavy Rain}

Figure 8 presents the simulated 1000-hPa geopotential height, winds, and maximum radar reflectivity. The radar reflectivity at each grid point was first calculated based on the simulated rain, ice, and snow mixing ratios. The maximum $\mathrm{dBZ}$ in a vertical column was then chosen to represent the radar reflectivity at that location. At $14 \mathrm{~h}$ of the simulation the Mei-yu front was located at the central TS and central Taiwan, extending northeastward to the east of Taiwan (Fig. 8a). Weak convection occurred near the front, while stronger convection happened farther to the south of the front. MCS $\mathrm{C}$ over southern Taiwan corresponded well with the observation at 0200 UTC 12 June 2005 (Fig. 6a). MCS D over the (a)
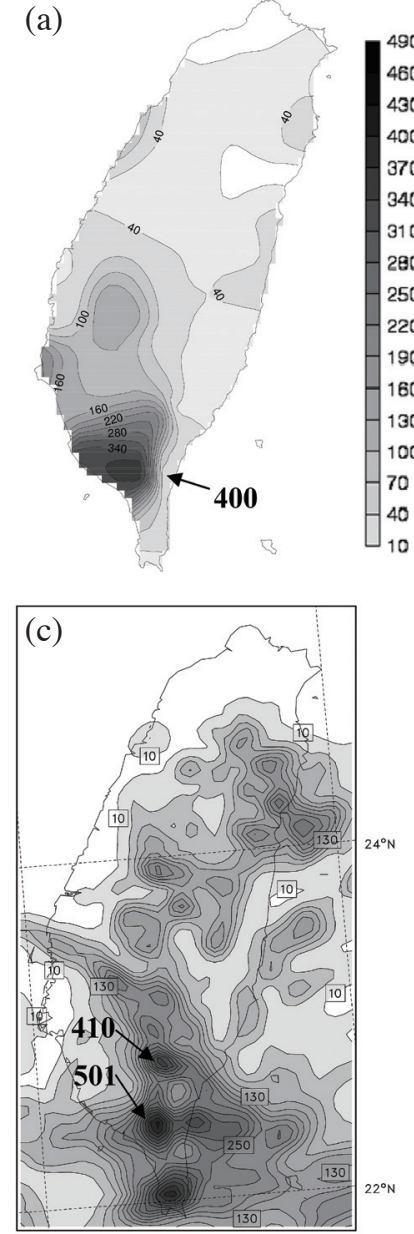

(b)
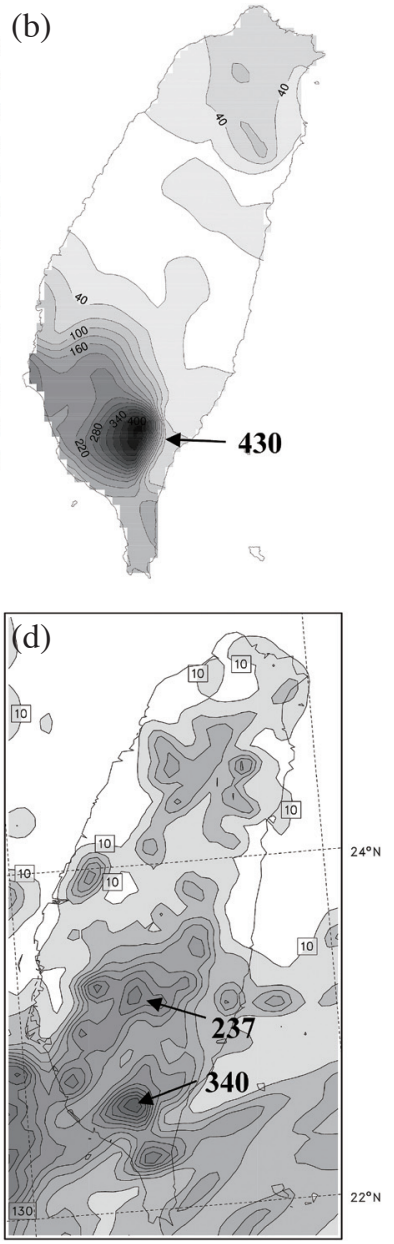

Fig. 7. The observed 24-h accumulated rainfall (mm) in Taiwan (a) from 1200 UTC 11 June to 1200 UTC 12 June 2005, and (b) from 1200 UTC 12 June to 1200 UTC 13 June 2005. The simulated rainfall (mm) from domain 3 at (c) $0-24 \mathrm{~h}$ and (d) $24-48 \mathrm{~h}$. The contour interval is $30 \mathrm{~mm}$, with scale shown on the middle top and maximum rainfall amounts denoted. 

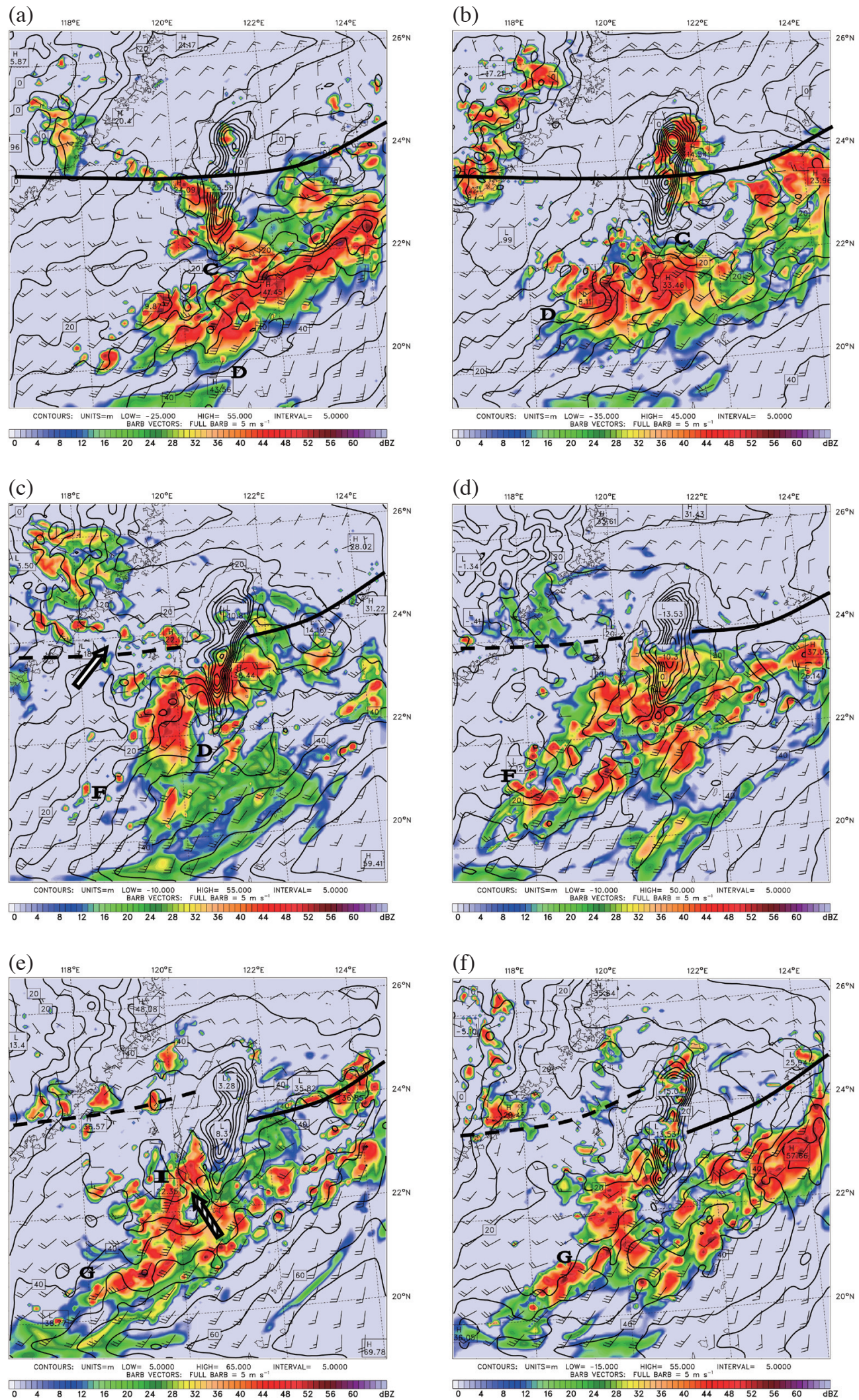

Fig. 8. Maximum radar reflectivity (shading, with dBZ scale shown in bottom), 1000-hPa geopotential height (contour lines at a 5-gpm interval) and winds (full barb is $5 \mathrm{~m} \mathrm{~s}^{-1}$ ) of domain 3 at (a) $14 \mathrm{~h}$ (0200 UTC 12 June 2005), (b) $20 \mathrm{~h}$ (0800 UTC 12 June), (c) $26 \mathrm{~h}$ (1400 UTC 12 June), (d) 32 $\mathrm{h}$ (2000 UTC 12 June), (e) $38 \mathrm{~h}$ (0200 UTC 13 June), and (f) $41 \mathrm{~h}$ (0500 UTC 13 June). The frontal location is indicated by thick solid and dashed lines. Convective bands $\mathrm{Y}$ and $\mathrm{Z}$ are indicated by hollow and hatched arrows, respectively. MCSs corresponding to Figs. 5 and 6 are denoted by upper-case letters. 
Luzon Strait also agreed well with the observation, but the convection was too strong southeast to Taiwan. Six hours later (Fig. 8b), southwesterly winds over the northern SCS and the Luzon Strait intensified. As a result, convection to the south of Taiwan enhanced and turned into more organized MCSs. MCS D was in good agreement with the observed radar reflectivity at 0800 UTC 12 June (Fig. 6a), but MCS C was a little too strong.

By $26 \mathrm{~h}$ the MCS C had moved overland and produced rainfall in southern Taiwan. At this time the simulated radar reflectivity shows a convective band (denoted by Y) across the central TS near the windshift zone of the front (Fig. 8c). The location of this convective band was close to that observed from radars at 1400 UTC 12 June 2005 (Fig. 6a). To the southwest of Taiwan MCS D developed because the warm, moist, and unstable southwesterly flow was lifted by the upward motion resulting from wind speed convergence and cyclonic vorticity over the southern TS. MCS F was beginning to develop farther to the southwest. Six hours later (Fig. 8d) convective band Y had moved southward and dissipated over the southern TS. The convergence associated with the windshift line of the front had weakened over the central TS. The front was difficult to identify near this region because it had become a broad zone of insignificant trough with weak winds. Only sporadic radar reflectivity remained over the TS. The majority of large radar reflectivity occurred over southern Taiwan and to the southwest of Taiwan (MCS F). The strong convection over southern Taiwan was a remnant of the aforementioned MCSs (C and D) that moved overland from the southwest. Comparisons show that convective band $\mathrm{Y}$ in observation appeared to last longer and move farther southward from 1100 UTC to 2000 UTC 12 June 2005 (Fig. 6), suggesting that the simulated front over the TS might be too weak and the evolution of convective band $\mathrm{Y}$ was not well captured. However, since convective band $\mathrm{Y}$ was not the primary contributor of rainfall in southern Taiwan, such a weakness in the simulation should not be critical.

At $38 \mathrm{~h}$ (Fig. 8e), the southwesterly flow intensified and the scattered MCSs enhanced and organized into MCS I that developed in an environment of strong low-level shear vorticity associated with flow confluence and large convergence over southwestern Taiwan and offshore to the southwestern coast. The convergence produced an upward motion and provided a trigger mechanism for the release of instability in the moist unstable southwesterly flow. A mesolow was present near MCS I over the southern TS as a result of latent heat release of strong convection. The convection in this area was slightly weaker than the observed convective band $\mathrm{Z}$ at 0200 UTC 13 June (Fig. 6b). The southward extension part of the convective band $\mathrm{Z}$ corresponding to MCS G (refer to Figs. $5 \mathrm{~g}, 6 \mathrm{~b}$ ) moved into the domain from the southwesterly flow upstream area. Three hours later at $41 \mathrm{~h}$ the convection near the southwestern coast of Taiwan had weakened
(Fig. 8f). Over the northern SCS MCS G was consistent with the observation at 0500 UTC 13 June (Fig. 6b), but MCSs over the ocean east of Taiwan appeared to be too strong.

In summary, the simulated radar reflectivity at the chosen times might not be perfectly matched with the observations in terms of intensity, formation time, and location. However, the model did capture the general continuous convection pattern that went on and off over the southern TS and the northern SCS after carefully reviewing the entire simulation at every hour. In addition, the heavy rainfall over southern Taiwan was closely reproduced as mentioned before. Using the model output, this paper examines the causes of heavy rain and the MCS formation mechanism and its relationship with the southwesterly flow.

\subsection{The Southwesterly Flow}

The low-level structure of the southwesterly flow is investigated using the $850-\mathrm{hPa}$ geopotential height, winds, and water vapor mixing ratio from domain 2. At $20 \mathrm{~h}$ (Fig. 9a) a low with moisture-laden air was located over southern China. A small region of moist air with water vapor exceeding $16 \mathrm{~g} \mathrm{~kg}^{-1}$ (indicated by a dark arrow) over east of Hainan Island (see Fig. 5a for location) was associated with low clouds (see Fig. 5d) and a short-wave trough that extended southward from the low. Over the northern SCS where the pressure gradient was large, a belt of strong southwesterly winds $\left(\geq 15 \mathrm{~m} \mathrm{~s}^{-1}\right)$ associated with high humidity extended from the southwest corner of the domain to the ocean southeast of Taiwan. These winds turned clockwise with height onto a more southwesterly direction at $850 \mathrm{hPa}$, compared to those at $1000 \mathrm{hPa}$ (Fig. 8b). This suggests the presence of warm advection in the southwesterly flow. Wind speeds decreased toward the northwest, resulting in strong shear vorticity southwest of Taiwan. To the north of the surface front where easterly winds were found at $1000 \mathrm{hPa}$ (Fig. 8b), the winds were very weak at $850 \mathrm{hPa}$ (Fig. 9a). This finding indicates that the windshift pattern associated with the front was quite shallow.

At $26 \mathrm{~h}$ (Fig. 9b) southwesterly winds over the southern TS and the northern SCS intensified mainly because of the northwestward extension of the ridge that was situated over the southeastern portion of the domain. The ridge was associated with a southwestward-extended part of the Pacific subtropical high (refer to Figs. $1 \mathrm{~b}$ and $2 \mathrm{~b}$ ) and its movement was evident by comparing, for example, the 1460-gpm contour line between Figs. 9a and b. Extending from southwest to northeast near Taiwan, the strong southwesterly flow was associated with large water vapor mixing ratio. The aforementioned small region of moist air had moved eastward near $115^{\circ} \mathrm{E}, 20^{\circ} \mathrm{N}$ by this time. Six hours later (Fig. 9c) it moved farther downstream and was associated with strong convection (MCS F in Figs. 5f, 6b, and 8d). The air was then warmed by the latent heat release of the convection, resulting in a slightly deeper trough. 
At $38 \mathrm{~h}$ the southwesterly flow had a maximum wind speed reaching approximately $20 \mathrm{~m} \mathrm{~s}^{-1}$ and a maximum water vapor mixing ratio exceeding $16 \mathrm{~g} \mathrm{~kg}^{-1}$ over southwestern Taiwan and offshore (Fig. 9d). Because of a pressure reduction due to latent heat release by the convection the short-wave trough had deepened and moved into this region. Such an environment was favorable for the development of MCS I associated with a southwest-northeast oriented convective band $\mathrm{Z}$ (see Figs. 6b, 8e). The MCS G that connected to the southwest of convective band $\mathrm{Z}$ in Fig. 8e formed mainly because of the continuous moisture supply by the strong southwesterly.

\subsection{Vertical Structure of the Southwesterly Flow}

The southwesterly flow was further investigated along a southwest-northeast cross section CE (marked in Fig. 3b) using data from domain 3 . At $14 \mathrm{~h}$ the air below $\sim 5 \mathrm{~km}$ was potentially unstable and the largest instability was confined in a shallow layer of $\sim 1 \mathrm{~km}$ AGL (Fig. 10a). Southwesterly winds at low levels were not particularly strong $\left(\leq 15 \mathrm{~m} \mathrm{~s}^{-1}\right)$ at this time. However, a strong convective band, corresponding to the MCS C near southern Taiwan in Fig. 8a, still developed offshore at about $400 \mathrm{~km}$ of the cross section. The offshore convective band moved overland and dissipated at a later time (Fig. 10b), resulting in heavy rainfall in southern Taiwan during the first day $(0-24 \mathrm{~h})$ of the simulation. At $20 \mathrm{~h}$ (Fig. 10b) southwesterly winds increased greatly with a maximum of about $20 \mathrm{~m} \mathrm{~s}^{-1}$ at $\sim 260 \mathrm{~km}$. The height was confined below $\sim 2 \mathrm{~km}$ AGL, suggesting the formation of an LLJ in the southwesterly flow. Near the leading edge of the LLJ, an intense convective band (MCS D in Fig. 8b) with a maximum upward motion of $\sim 1.4 \mathrm{~m} \mathrm{~s}^{-1}$ developed as a result of strong low-level convergence between the LLJ and the weaker flow ahead.
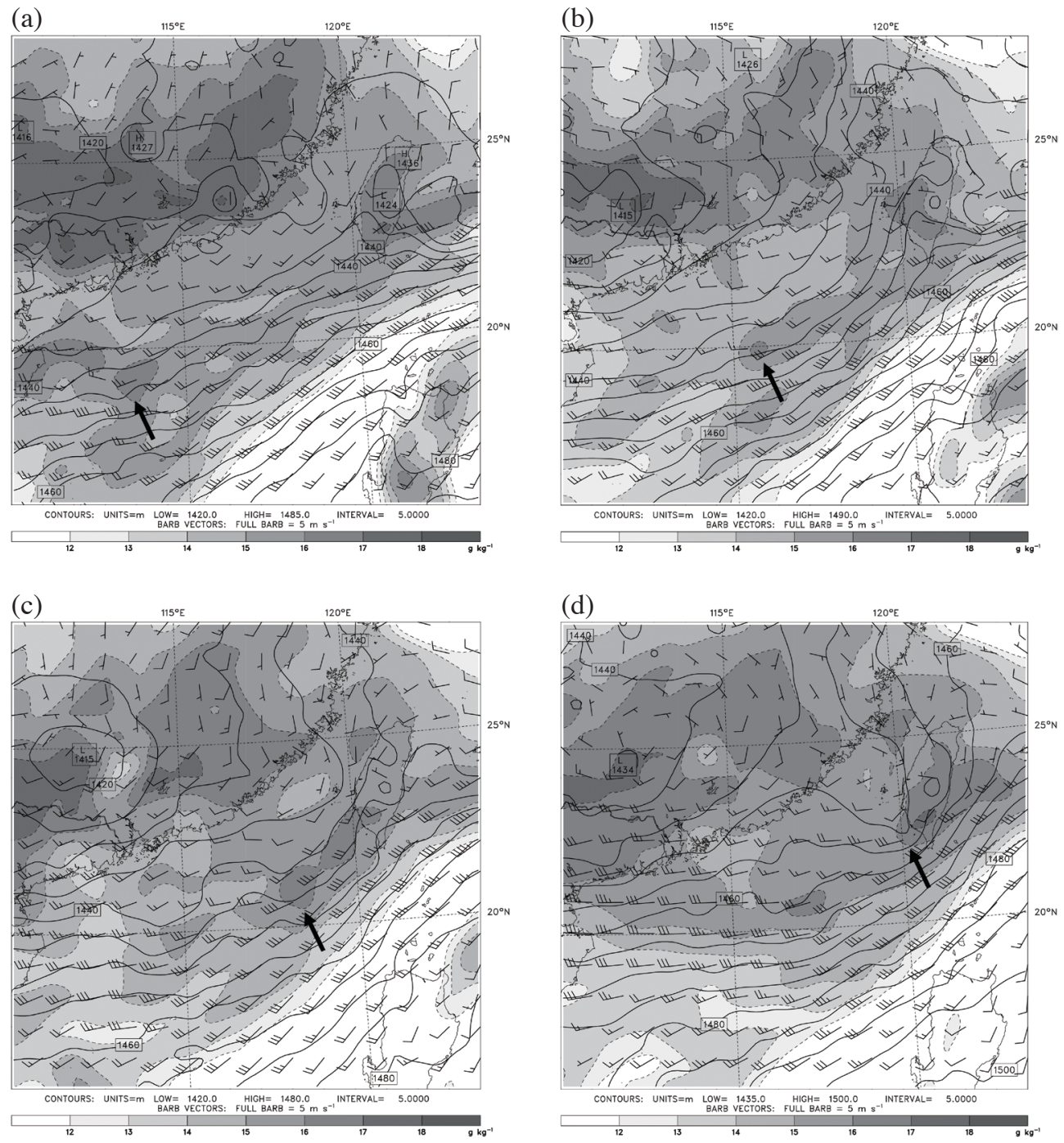

Fig. 9. The 850-hPa water vapor mixing ratio (shading and dashed lines, with scale shown in bottom; $\mathrm{g} \mathrm{kg}^{-1}$ ), geopotential height (solid lines with a 5-m interval), and wind barbs (full bar: $5 \mathrm{~m} \mathrm{~s}^{-1}$ ) of domain 2 at (a) $20 \mathrm{~h}$ (0800 UTC 12 June), (b) $26 \mathrm{~h}$ (1400 UTC 12 June), (c) $32 \mathrm{~h}$ (2000 UTC 12 June), and (d) $38 \mathrm{~h}$ (0200 UTC 13 June). A short-wave trough with moister air is indicated by an arrow. 
(a)

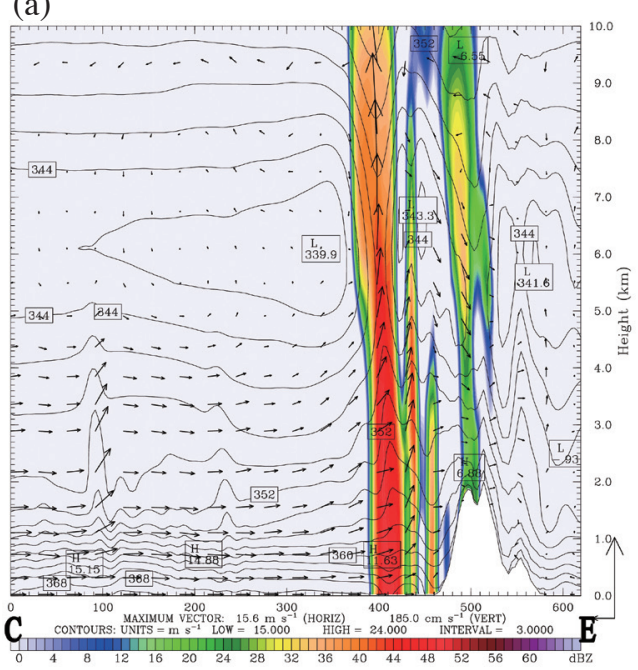

(c)

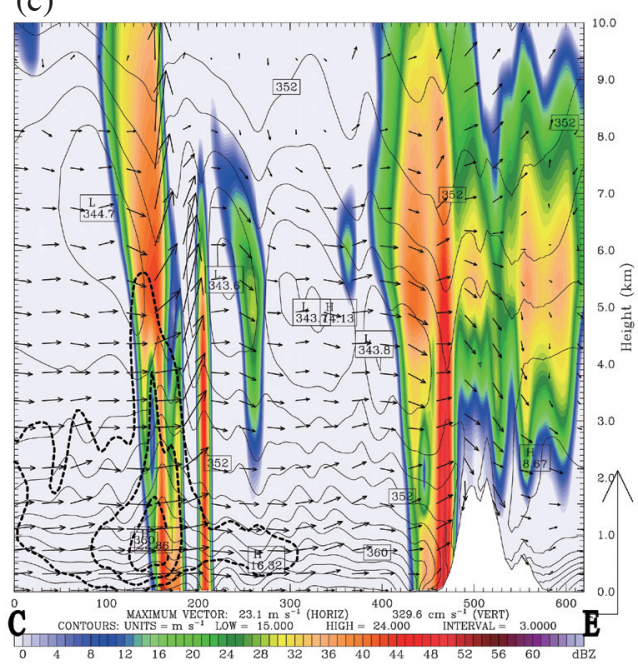

(b)

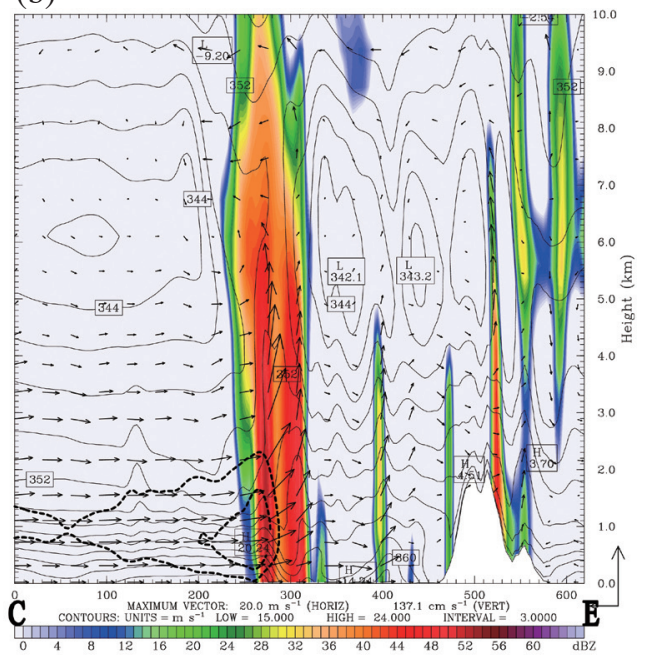

(d)

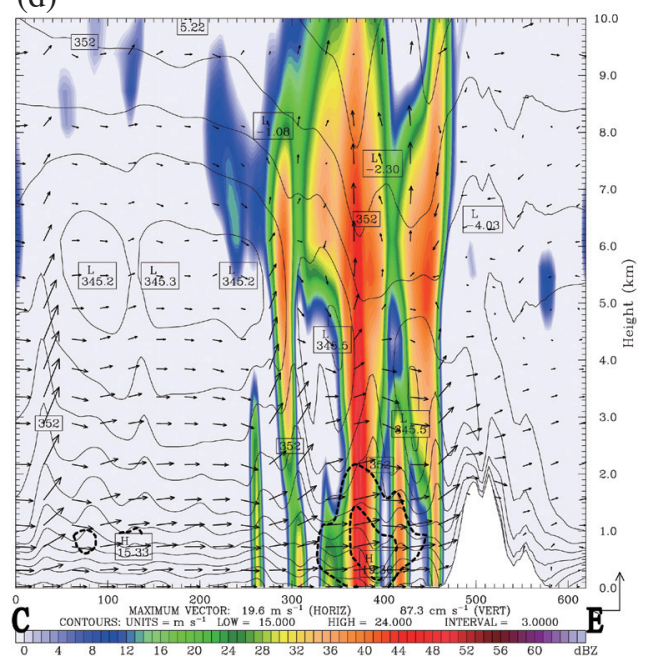

Fig. 10. Simulated radar reflectivity (color, dBZ), equivalent potential temperature (contour lines at a 2-K interval), and wind vectors (scale shown in the lower right) of domain 3 along cross section CE (location shown in Fig. 3b) at (a) 14 h (0200 UTC 12 June 2005), (b) 20 h (0800 UTC 12 June), (c) $32 \mathrm{~h}$ (2000 UTC 12 June), and (d) $38 \mathrm{~h}$ (0200 UTC 13 June). Along-section winds greater than $15 \mathrm{~m} \mathrm{~s}^{-1}$ are plotted in dashed lines with a $3 \mathrm{~m} \mathrm{~s}^{-1}$ interval.

After the MCS D moved over land and dissipated the southwesterly flow weakened slightly for a short period of time. At $32 \mathrm{~h}$ the southwesterly flow intensified again at $100-200 \mathrm{~km}$ (Fig. 10c), with the maximum horizontal wind of the jet core exceeding $23 \mathrm{~m} \mathrm{~s}^{-1}$ at approximately $170 \mathrm{~km}$ and strong wind $\left(>15 \mathrm{~m} \mathrm{~s}^{-1}\right)$ extending upward to $\sim 4 \mathrm{~km}$ AGL. Relatively weaker convection occurred near the leading edge of the LLJ corresponding to the short-wave trough (see Fig. 9c) and the associated MCS F (see Fig. 8d). The convective cloud band over land was a result of MCSs C and $\mathrm{D}$, which were further enhanced over mountain slopes. The southwesterly LLJ kept pushing toward the northeast. By $38 \mathrm{~h}$ the LLJ and the associated short-wave trough had arrived offshore of the southwestern coast of Taiwan (Fig. 10d). The maximum wind speed was approximately $19.6 \mathrm{~m} \mathrm{~s}^{-1}$ below $1 \mathrm{~km}$ AGL near the $400 \mathrm{~km}$ mark. At the leading edge of the strong wind (the $\sim 380 \mathrm{~km}$ mark) a band of deep clouds was associated with convective band Z (or MCS I; Fig. 8e). This cloud band moved northeastward overland at a later time. The convection was significantly enhanced over land where it combined with pre-existing intense convection, resulting in heavy rainfall on the second day of the simulation.

\section{RELATIONSHIP BETWEEN THE SOUTHWESTERLY FLOW AND MCS FORMATION}

Figure 11 shows time evolution (Hovmoller diagram) of selected fields along the south-north cross section $\mathrm{AB}$ (marked in Fig. 3b). MCS D over the northern SCS (point A) developed early at $\sim 12 \mathrm{~h}$ (Fig. 11a). They became stronger and extended northward along the cross section over 
time. Near the frontal zone (200 - $300 \mathrm{~km}$ of the cross section) convection kept developing because of the unstable environment. For example, convection first developed at $\sim 300 \mathrm{~km}$ before $12 \mathrm{~h}$, but it dissipated by $\sim 18 \mathrm{~h}$. At $\sim 24 \mathrm{~h}$ convection formed again at $\sim 330 \mathrm{~km}$ and it moved southward slightly over time. This was associated with convective band Y north of the front in Fig. 8c. To the south of the front at $\sim 230 \mathrm{~km}$ convection developed at $\sim 18 \mathrm{~h}$ and combined with the aforementioned northward-moving MCS $\mathrm{D}$, resulting in strong convection at $\sim 200 \mathrm{~km}$ at $\sim 30 \mathrm{~h}$. After that, except for a few remnants of convection near the front, the majority of convective activity moved southward along the cross section. This set up a stage for the development of convective band $\mathrm{Z}$, which occurred at $\sim 120 \mathrm{~km}$ at $36-42 \mathrm{~h}$ and then moved southward along the cross section. This convective band was also partly contributed by another con- vection associated with MCS F (Fig. 8d) that formed at the southern end of the cross section at $30-36 \mathrm{~h}$ and moved northward along the cross section. The convection activity significantly weakened after $48 \mathrm{~h}$.

The maximum CAPE and the average low-level water vapor mixing ratio (Figs. $11 \mathrm{~b}$ and c) show that at $\sim 12 \mathrm{~h}$ the flow over the northern SCS and the southern TS (the $0-100 \mathrm{~km}$ mark) was particularly unstable (large CAPE) and moist. This zone extended northward to the area near the front (200 - $300 \mathrm{~km})$. In addition, low-level convergence was present at these locations, judging from the large gradient of low-level along-section wind speed (Fig. 11d). In the south the convergence was a result of the wind difference near the leading edge of the southwesterly flow, whereas in the north it was associated with the front. Such convergence produced an upward motion that provided a trigger mechanism (a)

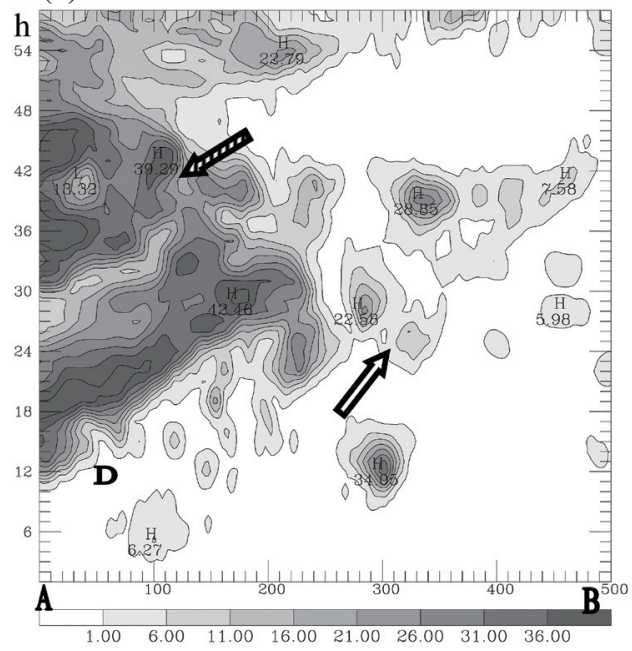

(c)

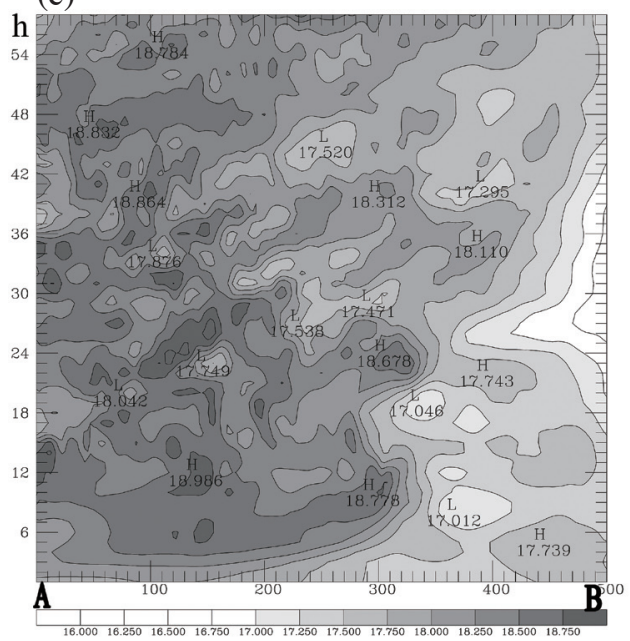

(b)

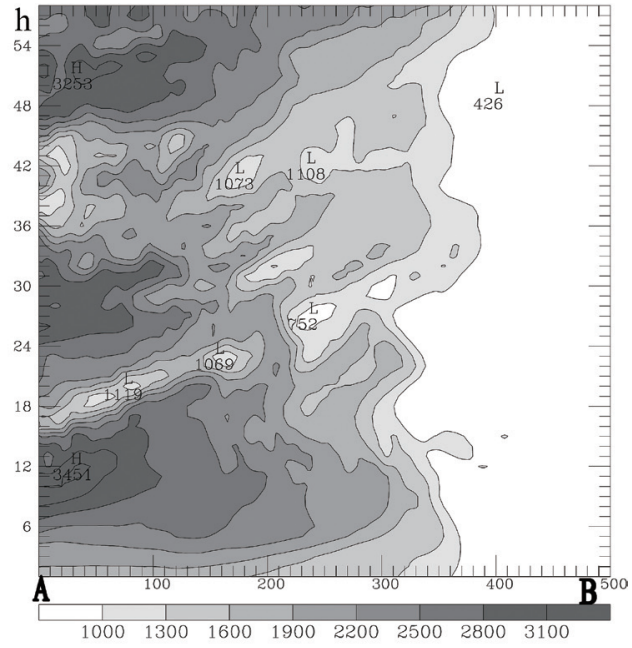

(d)

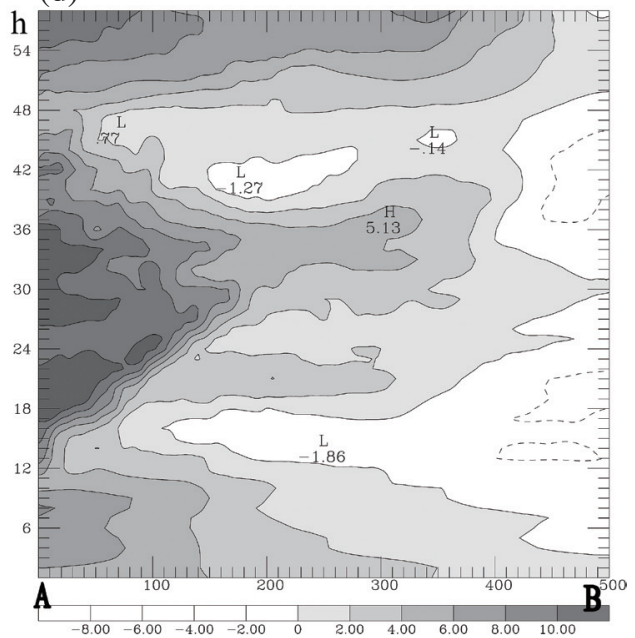

Fig. 11. Time evolution of (a) maximum radar reflectivity (dBZ), (b) maximum CAPE ( $\left.\mathrm{Jg}^{-1}\right)$, (c) water vapor mixing ratio (g kg $\left.\mathrm{g}^{-1}\right)$, and (d) alongsection wind ( $\mathrm{m} \mathrm{s}^{-1}$, positive velocity denotes a toward-the-right wind direction) of domain 3 along cross section AB (location shown in Fig. 3 b). Fields in (c) and (d) are averaged below $850 \mathrm{hPa}$. The ordinate is time from $1-58 \mathrm{~h}$ of model simulation, and the abscissa is distance in km. Shading indices are shown in bottom with solid lines denoting positive and dashed lines representing negative values. Convective bands $\mathrm{Y}$ and $\mathrm{Z}$ are denoted by hollow and hatched arrows, respectively, and MCS D is indicated by capital letter D. 
for the release of conditional/potential instability in the southwesterly flow. The strong southwesterly flow pushed northward at $18-30 \mathrm{~h}$ and then weakened after $\sim 36 \mathrm{~h}$. Only after $48 \mathrm{~h}$ did the strong southerly along-section winds push all the way northward. The intensity of southerly alongsection winds had good correlation with the aforementioned convective activity. In other words, convection developed as a result of strong southwesterly winds because they brought unstable and moist air to the region. Figure $11 \mathrm{~b}$ shows three periods of large CAPE in the southern portion of the cross section, which corresponded to those of the strong southerly wind component in the southwesterly flow. CAPE became smaller after strong convection broke out. However, CAPE increased again through the supply of unstable air by the southwesterly flow.

Time evolution was also examined along cross section $\mathrm{CD}$ (see Fig. 3b for location) to better study the southwesterly flow. At early hours ( 0 - $12 \mathrm{~h})$, MCS C was already pres- ent near the southwestern coast of Taiwan $(\sim 400 \mathrm{~km}$ of the cross section, Fig. 12a). They developed in an environment of pre-existing southwesterly flow with moist and unstable air (Figs. 12b - d). After $\sim 12 \mathrm{~h}$, the southwesterly flow started to increase at $0-100 \mathrm{~km}$ and it pushed northeastward along the cross section over time, reaching its maximum near the southwestern coast of Taiwan at $\sim 24 \mathrm{~h}$ (Fig. 12d). This period is referred to as the first push of the southwesterly flow. After the first push the southwesterly wind speed reduced a little for about $8 \mathrm{~h}$. Starting from $\sim 26 \mathrm{~h}$ southwesterly flow strengthened again at the southwestern end of the cross section, and then gradually pushed northeastward, approaching the southwestern coast of Taiwan at $\sim 40 \mathrm{~h}$. This period is referred to as the second push of the southwesterly flow.

The above southwesterly flow wind speed increases were in concurrence with two major convective bands shown in simulated radar reflectivity (Fig. 12a). The first one, which was associated with the MCS D during the first push of the (a)

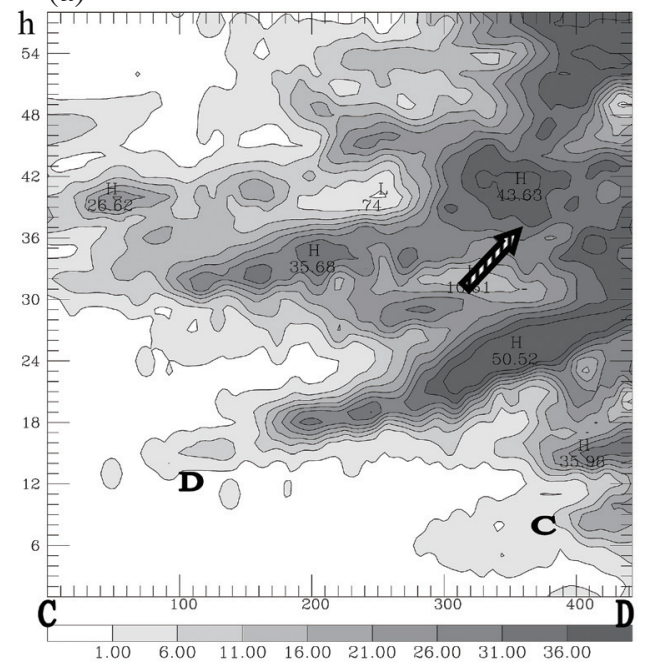

(c)

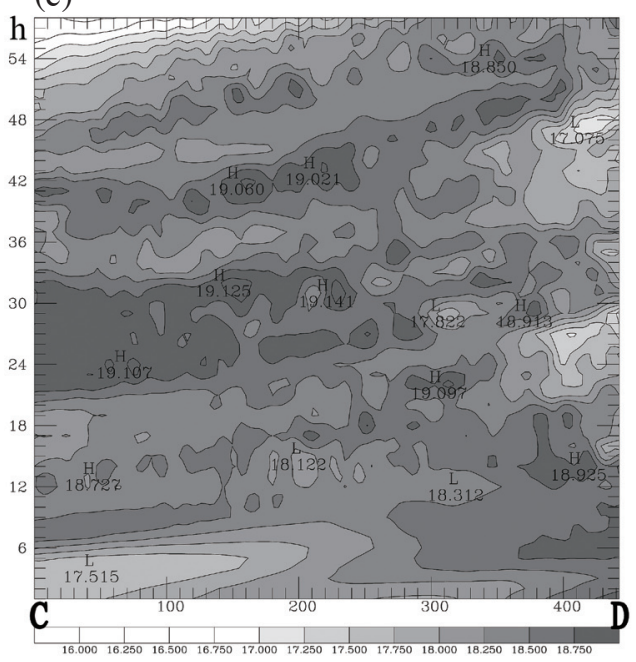

(b)

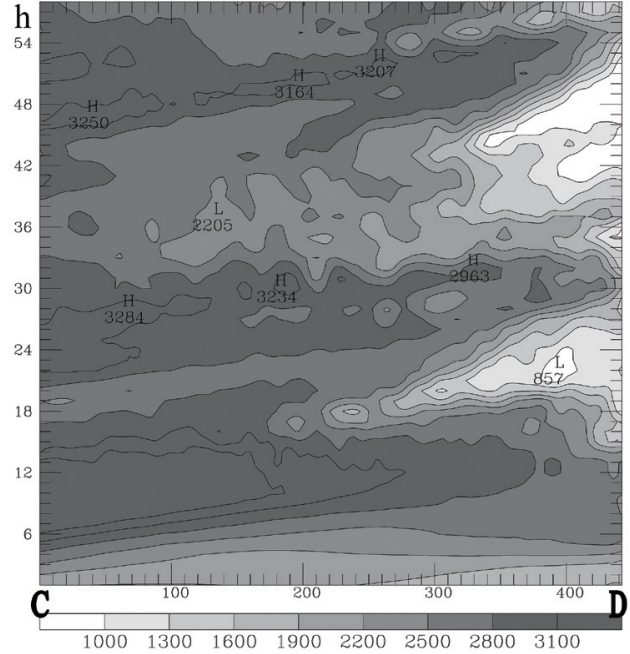

(d)

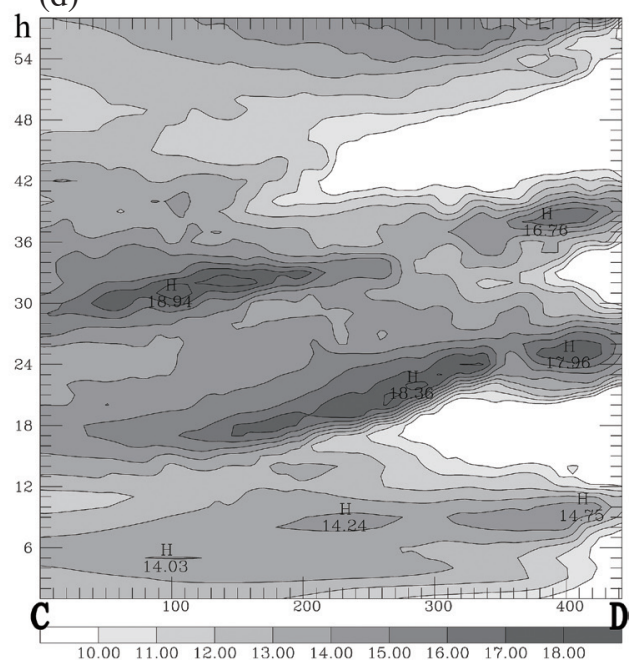

Fig. 12. Same as Fig. 11, but for cross section CD (location shown in Fig. 3b). 
southwesterly flow, occurred near $100 \mathrm{~km}$ at approximately $14 \mathrm{~h}$ and moved toward the shore over time. It contributed to the heavy rainfall in southern Taiwan on the first day. The second convective band, which was mainly associated with MCS F in Figs. 8c, d, initiated during the second push of the southwesterly flow, developed near the southwestern end of the cross section around $30 \mathrm{~h}$, and then intensified and moved northeastward over time. As discussed in Fig. 9 this northeastward-moving convective band can be traced farther upstream offshore of the southern coast of China. The band was associated with MCS F at early time as the short-wave trough moved into the domain. At a later time the band intensified and was associated with MCSs G and I (or convective band Z). The MCSs embedded in the convective band $\mathrm{Z}$ moved overland and produced heavy rainfall in southern Taiwan on the second day. Similar to that found in Fig. 11b, low

(a)

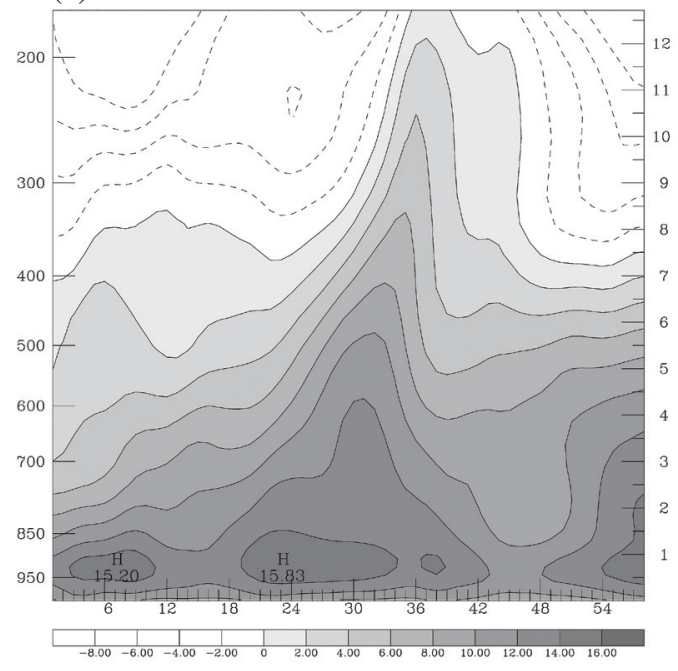

(c)

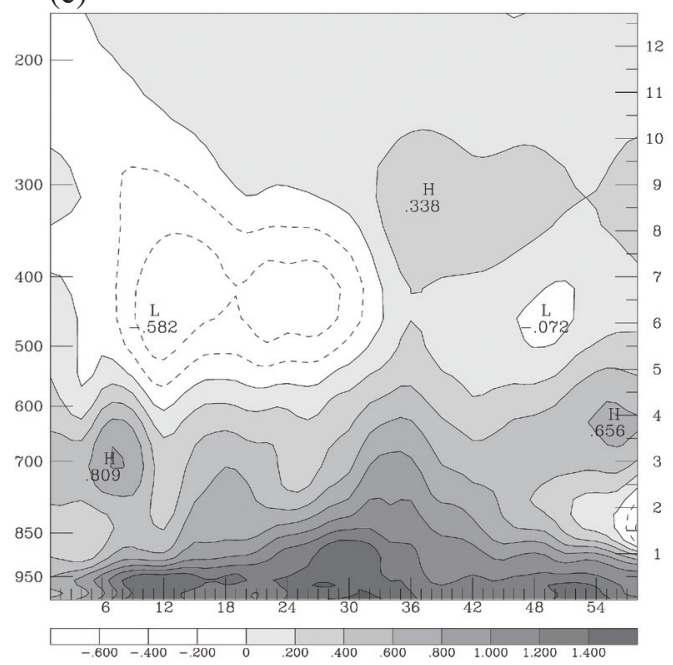

CAPE (Fig. 12b) was associated with large radar reflectivity. It is evident that the southwesterly flow was associated with large CAPE before convection initiation. After the southwesterly flow intensified and the MCS developed the instability was released and the CAPE became significantly smaller. These simulated CAPEs near the southwestern end (point $\mathrm{C}$ of Fig. 3b) of the cross section agreed well with the sounding observation at Tongsha Island which had a slightly larger CAPE $\left(\sim 2800 \mathrm{~m}^{2} \mathrm{~s}^{-2}\right)$ at 0000 UTC 12 June (figure not shown) than at 0000 UTC 13 June $\left(\sim 2400 \mathrm{~m}^{2} \mathrm{~s}^{-2}\right.$, see Fig. 4). The amount of moisture (Fig. 12c) in the southwesterly flow had a trend similar to that of CAPE, indicating that the southwesterly flow was unstable and moist and was favorable for the development of MCSs.

Figure 13 shows a time evolution of southwesterly wind component, vertical velocity, and water vapor perturbation (b)

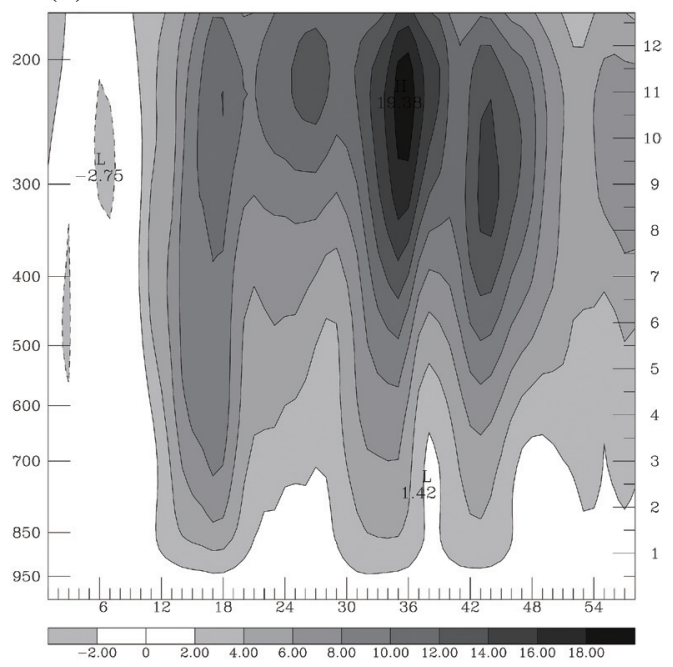


averaged inside box CFDG (see Fig. 3b for location). The water vapor perturbation was obtained by first computing the horizontally averaged water vapor mixing ratio at each vertical level within domain 3 and then subtracting it from the water vapor mixing ratio at each corresponding 3-D point. This field helps to determine whether air at a particular location is relatively moist or dry in a time-height section. The low-level southwesterly wind speed average in box CFDG started to increase at $18 \mathrm{~h}$ during the first push and the strong wind altitude extended upward over time (Fig. 13a). The maximum wind speed of $\sim 16 \mathrm{~m} \mathrm{~s}^{-1}$ occurred before $\sim 24 \mathrm{~h}$ at 850 - $950 \mathrm{hPa}$. There was another maximum at $\sim 38 \mathrm{~h}$ during the second push. Note that because this was a domainaveraged wind speed, winds at individual locations could be much stronger. It is therefore evident that an LLJ existed in this area. Two large upward motion periods were in concurrence with those of maximum winds. The first happened at $12-18 \mathrm{~h}$ and the second, which had a larger maximum domain-averaged vertical velocity of $\sim 19 \mathrm{~cm} \mathrm{~s}^{-1}$, occurred at $30-36 \mathrm{~h}$ (Fig. 13b). There was another strong updraft occurring at $42-48 \mathrm{~h}$. These upward motions all corresponded well to the strong convection periods in the area, as seen in Fig. 12a. The water vapor perturbation shows that lowlevel air increased in moisture content early in the simulation and the moist air extended upward over time (Fig. 13c). In particular, the largest perturbation at low level occurred at around 12 and $30 \mathrm{~h}$. This tendency was consistent with horizontal wind speed (Fig. 13a), indicating that the LLJ played an important role in transporting moisture into the area.

\section{THE SOUTHWESTERLY FLOW INTENSIFICATION MECHANISMS}

To further examine the southwesterly flow intensification mechanisms over the northern SCS and the southern TS, the momentum budget was calculated using domain 3 data. The momentum equations can be simply written as follows:

$$
\begin{aligned}
& \frac{\partial u}{\partial t}=-V_{h} \cdot \nabla u-w \frac{\partial u}{\partial z}+f v-\frac{1}{\rho} \frac{\partial p}{\partial x}+R_{x} \\
& \frac{\partial v}{\partial t}=-V_{h} \cdot \nabla v-w \frac{\partial v}{\partial z}-f u-\frac{1}{\rho} \frac{\partial p}{\partial y}+R_{y}
\end{aligned}
$$

where the terms on the left are local change of momentum (LC), and the terms on the right are, in corresponding order, horizontal advection (HA), vertical advection (VA), Coriolis force (CF), pressure gradient force (PGF), and the residual which accounts for friction, momentum mixing, and numerical errors. The residual terms are not shown in this paper because they are, in general, relatively small over the ocean. The coordinate system was transformed such that the $\mathrm{x}$-component is directed toward the northeast and parallel to the southwesterly flow (hereafter, the NE direction), and the y-component is perpendicular to the southwesterly flow toward the northwest (hereafter, the NW direction). Note that because airflow may not be well dynamically balanced during the model spinup stage, the budget at $0-6 \mathrm{~h}$ is mostly ignored.

Figure 14 presents the $850-\mathrm{hPa}$ momentum budget averaged inside box CFDG (see Fig. $3 b$ for location) in the NE and NW directions. At early hours (6 - 10 h), PGF (curve 5) in the NE direction, which was positive and larger than the combined negative CF (curve 4) and HA (curve 2), contributed to the positive LC (curve 1), resulting in the pre-existing
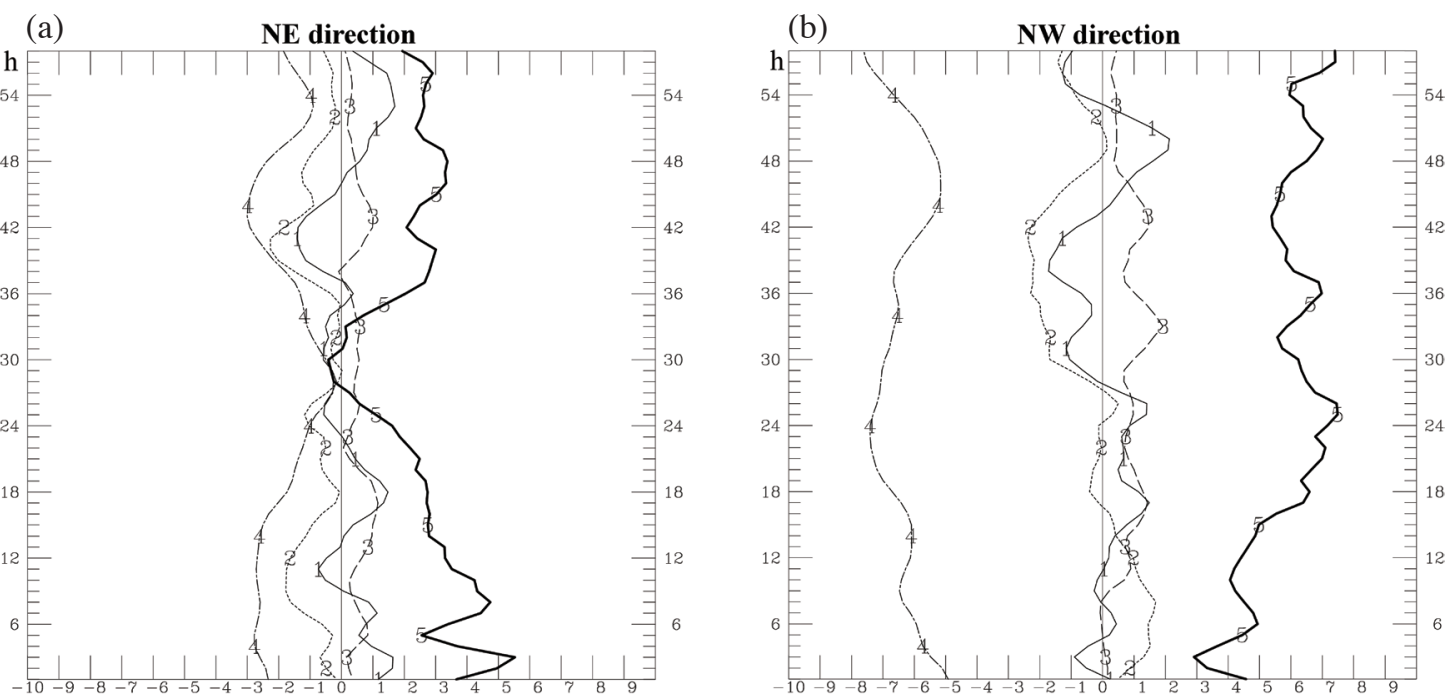

Fig. 14. Time evolution of momentum budgets in the (a) northeastward and (b) northwestward directions along line CD at $850 \mathrm{hPa}$ averaged inside box CFDG (location shown in Fig. 3b). Curves 1 - 5 denote local change (LC), horizontal advection (HA), vertical advection (VA), Coriolis force $(\mathrm{CF})$, and pressure gradient force (PGF), respectively. The ordinate is time from $1-58 \mathrm{~h}$ of model simulation, and the abscissa is magnitude (unit: $\left.1 \times 10^{-4} \mathrm{~m} \mathrm{~s}^{-2}\right)$. 
southwesterly flow over the northern SCS (Fig. 14a). During this time period the momentum budget in the NW direction was nearly in geostrophic balance between the large positive PGF and negative CF (Fig. 14b). However, PGF in the NW direction increased from $4 \times 10^{-4}$ to $7 \times 10^{-4} \mathrm{~m} \mathrm{~s}^{-2}$ at $10-26 \mathrm{~h}$, resulting in positive LC. This was associated with the northwestward extension of a ridge associated with the Pacific high as stated in section 3.3. Local wind in the NW direction thus increased slightly, which in turn caused an increase of CF in the NE direction from $-3 \times 10^{-4}$ to $-1.5 \times 10^{-4} \mathrm{~m} \mathrm{~s}^{-2}$ (Fig. 14a). PGF in the NE direction was therefore larger than $\mathrm{CF}$, resulting in positive $\mathrm{LC}$ at $14-24 \mathrm{~h}$ and thus acceleration in the southwesterly flow (the first push). The VA (curve 3 ) was also positive because convection could transfer large momentum to the $850 \mathrm{hPa}$ level. However, since it only occurred in a small portion of the domain, such forcing was smoothed out and became small after averaging. During this time period associated with the increase in the NW-directed PGF, PGF in the NE direction decreased because the isobars turned into a more southwest-northeast direction as a result of the aforementioned northwestward extension of the ridge. All forces in the NE direction became smaller at $24-30 \mathrm{~h}$.

After 30 h, PGF in the NE direction increased (Fig. 14a). This is related to the low pressure formation due to the shortwave trough and the latent heat release of convection over the northern SCS, as shown in Figs. 9c, d. Such a connection can be easily shown by the same fields, but from the data of domain 3 (Fig. 15). At $32 \mathrm{~h}$ the short-wave trough with a minimum height of $1434 \mathrm{gpm}$ moved into domain 3 over the northern SCS (Fig. 15a). Ahead of the trough many small low pressure areas resulted from pressure reduction due to latent heat release produced by the active MCSs there (see Fig. 8d). At this time the southwesterly flow in box CFDG was still strong. However, as the low pressure system moved
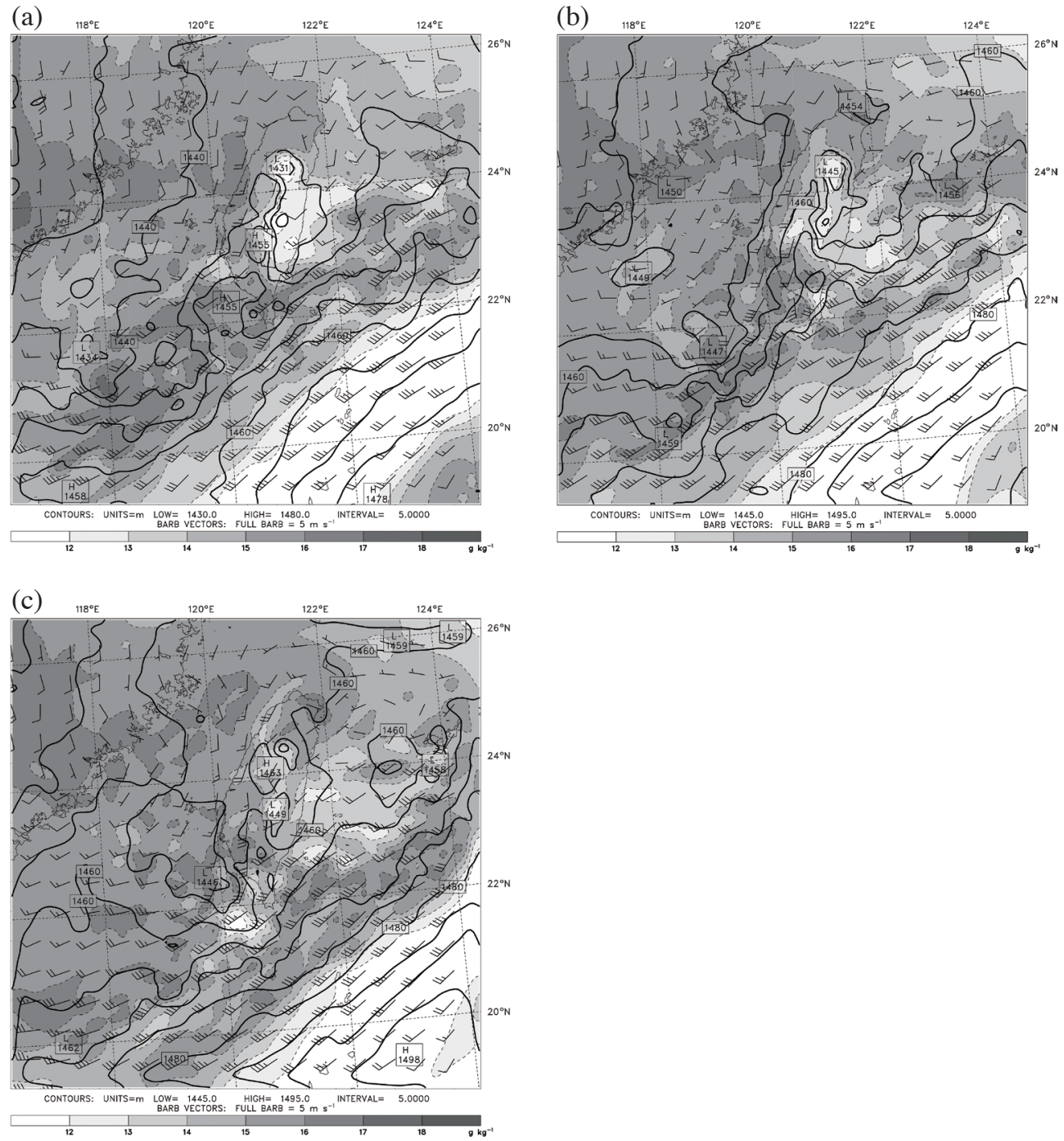

Fig. 15. The $850-\mathrm{hPa}$ water vapor mixing ratio (shading and dashed lines, with scale shown in bottom; $\mathrm{g} \mathrm{kg}^{-1}$ ), geopotential height (solid lines with a 5-m interval), and wind barbs (full bar: $5 \mathrm{~m} \mathrm{~s}^{-1}$ ) of domain 3 at (a) $32 \mathrm{~h}$ (2000 UTC 12 June), (b) $35 \mathrm{~h}$ (2300 UTC 12 June), and (c) $38 \mathrm{~h}$ (0200 UTC 13 June). 
northeastward winds behind the trough became westerly (Fig. 15b). From a broader view, the isobars near box CFDG switched from a southwest-northeast orientation at $20 \mathrm{~h}$ (see Fig. 9a) to a west-east orientation at 32 and 38 h (Figs. 9c, d). The PGF thus turned from a northwestward direction to a northward direction, resulting in the increase of the NE-directed PGF. Because of the down-gradient acceleration LC in the NE direction increased and became positive, corresponding to the second push of the southwesterly flow (Fig. 14a). However, the positive LC was not large and did not last long because the negative HA and CF magnitudes both increased after $36 \mathrm{~h}$. The reason for the large negative HA is better explained by comparing Figs. $15 \mathrm{~b}$ and c, which show that winds in the top left portion of box CFDG turned more westerly as the low pressure moved closer to the southwestern coast of Taiwan, while winds in the bottom right portion remained southwesterly. As a result the average HA in the box was directed southeastward at $30-36 \mathrm{~h}$ and then turned to southward after $36 \mathrm{~h}$, which corresponded to the negative HA in the NW direction after $\sim 30 \mathrm{~h}$ and the negative HA in the NE direction after $36 \mathrm{~h}$. Furthermore, the large negative $\mathrm{CF}$ is caused by the negative HA in the NW direction which, after being partly offset by the small positive VA and the small imbalance between PGF and CF, resulted in the negative LC at $30-42 \mathrm{~h}$. The NW component winds were thus reduced, causing a magnitude increase of negative $\mathrm{CF}$ in the NE direction. After $48 \mathrm{~h} \mathrm{LC}$ in the NE direction became positive again because of a down-gradient acceleration. This is however beyond the scope of this paper. Lastly, it is noteworthy that although not very large, the box-averaged VA had positive contribution to LC most of the time when convection was active in the area.

In summary, the first push of the southwesterly flow was contributed primarily by the northwestward extension of a ridge associated with the Pacific high. The second push was caused mainly by the northeastward movement of the shortwave trough and the pressure reduction associated with the convection. The LC of the second push was smaller than that of the first push because the pressure system in charge for the former was local scale as aforementioned such that other offset forces could rise as the PGF increased, while that for the latter was synoptic scale such that the PGF was dominant.

\section{SUMMARY AND CONCLUSIONS}

A heavy rain event that occurred in southern Taiwan from 11 to 13 June 2005 was studied in this research. Observations show that before 12 June a weak Mei-yu front was moving southeastward from China toward Taiwan, while MCSs were developing over the SCS in the strong southwesterly flow. The evolving MCSs southwest of Taiwan moved over land and resulted in heavy rainfall in southern Taiwan. The WRF model of 5-km horizontal resolution was capable of reproducing the heavy rain and capturing the southwesterly flow intensification process and the overall MCS formation features.

The heavy rain occurring in southern Taiwan on the first day (from 1200 UTC 11 to 1200 UTC 12 June 2005) was caused by the continuously-evolving MCSs that formed over the northern SCS and the southern TS, moved overland at a later time, and were further enhanced by the mountain slopes. The formation of these MCSs was related to the strengthening southwesterly flow that transported moist and unstable air into the region. As the wind speed increased an LLJ formed and the MCSs were triggered because the potentially unstable air was lifted in a low-level convergence and shearing vorticity environment. The northwestward extension of a ridge associated with the Pacific subtropical high was responsible for the wind speed increase in the southwesterly flow. This pressure pattern contributed first to an increase in northwestward directed pressure gradient force and a wind speed increase in that direction, which then resulted in Coriolis acceleration in the northeastward direction and the southwesterly flow intensification.

The continuous heavy precipitation in southern Taiwan on the second day (from 1200 UTC 12 to 1200 UTC 13 June 2005) was produced similarly as on the first day, but by other MCSs. The southwesterly flow intensification mechanisms were also different. They started with low pressure forming in the northern portion of the region because of the combined effect of a short-wave trough moving in from upstream associated with the southwesterly flow and a pressure reduction resulting from the latent heat release by the MCSs. The northeastward pressure gradient force consequently increased and the southwesterly flow intensified because of the down-gradient acceleration. However, the local wind acceleration of the southwesterly flow was smaller than that in the first day because the pressure system in charge for the former was local scale such that other forces also increased to offset the positive pressure gradient force, while that for the latter was synoptic scale such that the pressure gradient force was dominant. Lastly, the conclusions and meteorological conditions discussed in this paper can be used as guidance for predicting the formation and development of southwesterly flow over the northern SCS and estimating the probability for MCS formation and heavy rainfall in southern Taiwan.

Acknowledgements This research was supported by the Ministry of Science and Technology of Taiwan (Grants MOST 103-2111-M-003-003, NSC 102-2625-M-003-003, and NSC 100-2625-M-003-001). The author thanks the Central Weather Bureau for offering numerical and observational data, Miss Sandy Chen for performing the model simulation, and the two anonymous reviewers for providing constructive suggestions and comments. Special gratitude is given to Dr. Pao-Liang Chang and Dr. Pin-Fang Lin of the Central Weather Bureau for collecting the radar data and 
images. Our gratitude also goes to the Academic Paper Editing Clinic, NTNU.

\section{REFERENCES}

Chen, C. S. and Y. L. Chen, 2003: The rainfall characteristics of Taiwan. Mon. Weather Rev., 131, 1323-1341, doi: 10.1175/1520-0493(2003)131<1323:TRCOT>2.0 .CO;2. [Link]

Chen, C. S., Y. L. Chen, C. L. Liu, P. L. Lin, and W. C. Chen, 2007: Statistics of heavy rainfall occurrences in Taiwan. Weather Forecast., 22, 981-1002, doi: 10.1175/WAF1033.1. [Link]

Chen, G. T. J., 1983: Observational aspects of the Meiyu phenomena in subtropical China. J. Meteorol. Soc. Jpn., 61, 306-312.

Chen, G. T. J., 2004: Research on the phenomena of Meiyu during the past quarter century: An overview. In: Chang, C. P. (Ed.), East Asian Monsoon, World Scientific series on meteorology of East Asia Vol. 2, World Scientific, 357-403.

Chen, G. T. J. and C. C. Yu, 1988: Study of low-level jet and extremely heavy rainfall over northern Taiwan in the Mei-yu season. Mon. Weather Rev., 116, 884-891, doi: 10.1175/1520-0493(1988)116<0884:SOLLJA>2 . $0 . \mathrm{CO} ; 2$. [Link]

Chen, G. T. J. and C. Y. Liang, 1992: A midlevel vortex observed in the Taiwan Area Mesoscale Experiment (TAMEX). J. Meteorol. Soc. Jpn., 70, 25-41.

Chen, G. T. J., C. C. Wang, and D. T. W. Lin, 2005: Characteristics of low-level jets over northern Taiwan in Meiyu season and their relationship to heavy rain events. Mon. Weather Rev., 133, 20-43, doi: 10.1175/MWR2813.1. [Link]

Chen, G. T. J., C. C. Wang, and L. F. Lin, 2006: A diagnostic study of a retreating Mei-yu front and the accompanying low-level jet formation and intensification. Mon. Weather Rev., 134, 874-896, doi: 10.1175/MWR3099.1. [Link]

Chen, S. J., Y. H. Kuo, W. Wang, Z. Y. Tao, and B. Cui, 1998: A modeling case study of heavy rainstorms along the Mei-yu front. Mon. Weather Rev., 126, 2330-2351, doi: 10.1175/1520-0493(1998)126<2330:AMCSOH> 2.0.CO;2. [Link]

Chen, X. A. and Y. L. Chen, 1995: Development of lowlevel jets during TAMEX. Mon. Weather Rev., 123, 1695-1719, doi: 10.1175/1520-0493(1995)123<1695: DOLLJD>2.0.CO;2. [Link]

Chen, Y. L. and N. B. F. Hui, 1990: Analysis of a shallow front during the Taiwan Area Mesoscale Experiment. Mon. Weather Rev., 118, 2649-2667, doi: 10.1175/152 0-0493(1990)118<2649:AOASFD>2.0.CO;2. [Link]

Chen, Y. L., Y. X. Zhang, and N. B. F. Hui, 1989: Analysis of a surface front during the early summer rainy season over Taiwan. Mon. Weather Rev., 117, 909-931, doi: 10.1175/1520-0493(1989)117<0909:AOASFD>2.0.C O;2. [Link]

Chou, L. C., C. P. Chang, and R. T. Williams, 1990: A numerical simulation of the Mei-yu front and the associated low level jet. Mon. Weather Rev., 118, 1408-1428, doi: 10.1175/1520-0493(1990)118<1408:ANSOTM> 2.0.CO;2. [Link]

Colle, B. A., Y. Lin, S. Medina, and B. F. Smull, 2008: Orographic modification of convection and flow kinematics by the Oregon Coast Range and Cascades during IMPROVE-2. Mon. Weather Rev., 136, 3894-3916, doi: 10.1175/2008MWR2369.1. [Link]

Ding, Y., 1992: Summer monsoon rainfalls in China. J. Meteorol. Soc. Jpn., 70, 373-396.

Hong, S. Y., J. Dudhia, and S. H. Chen, 2004: A revised approach to ice microphysical processes for the bulk parameterization of clouds and precipitation. Mon. Weather Rev., 132, 103-120, doi: 10.1175/1520-0493 (2004)132<0103:ARATIM>2.0.CO;2. [Link]

Hong, S. Y., Y. Noh, and J. Dudhia, 2006: A new vertical diffusion package with an explicit treatment of entrainment processes. Mon. Weather Rev., 134, 2318-2341, doi: 10.1175/MWR3199.1. [Link]

Kain, J. S. and J. M. Fritsch, 1993: Convective parameterization for mesoscale models: The Kain-Fritsch scheme. In: Emanuel, K. A. and D. J. Raymond (Eds.), The Representation of Cumulus Convection in $\mathrm{Nu}$ merical Models, Meteorological Monographs, Vol. 24, American Meteorological Society, 246 pp, doi: 10.1175/0065-9401-24.46.1. [Link]

Kato, T., 1998: Numerical simulation of the band-shaped torrential rain observed over southern Kyushu, Japan on 1 August 1993. J. Meteorol. Soc. Jpn., 76, 97-128.

Kuo, Y. H. and G. T. J. Chen, 1990: The Taiwan Area Mesoscale Experiment (TAMEX): An overview. Bull. Amer. Meteorol.Soc., 71, 488-503, doi: 10.1175/15200477(1990)071<0488:TTAMEA>2.0.CO;2. [Link]

Lau, K. M., G. J. Yang, and S. H. Shen, 1988: Seasonal and intraseasonal climatology of summer monsoon rainfall over East Asia. Mon. Weather Rev., 116, 18-37, doi: 1 0.1175/1520-0493(1988)116<0018:SAICOS>2.0.CO; 2. [Link]

Li, J., Y. L. Chen, and W. C. Lee, 1997: Analysis of a heavy rainfall event during TAMEX. Mon. Weather Rev., 125, 1060-1082, doi: 10.1175/1520-0493(1997)125<1 060:AOAHRE $>2.0 . C O ; 2$. [Link]

Lin, Y. J., H. Shen, T. C. C. Wang, Z. S. Deng, and R. W. Pasken, 1990: Characteristics of a subtropical squall line determined from TAMEX dual-Doppler data. Part II: Dynamic and thermodynamic structures and momentum budgets. J. Atmos. Sci., 47, 2382-2399, doi: 10.1175/1520-0469(1990)047<2382:COASSL >2.0.C O;2. [Link] 
Lin, Y. J., R. W. Pasken, and H. W. Chang, 1992: The structure of a subtropical prefrontal convective rainband. Part I: Mesoscale kinematic structure determined from dual-Doppler measurements. Mon. Weather Rev., 120, 1816-1836, doi: 10.1175/1520-0493(1992)120<1816: TSOASP> 2.0.CO;2. [Link]

Nagata, M. and Y. Ogura, 1991: A modeling case study of interaction between heavy precipitation and a lowlevel jet over Japan in the Baiu season. Mon. Weather Rev., 119, 1309-1336, doi: 10.1175/1520-0493(1991)1 19<1309:AMCSOI>2.0.CO;2. [Link]

Ray, P. S., A. Robinson, and Y. Lin, 1991: Radar analysis of a TAMEX frontal system. Mon. Weather Rev., 119, 2519-2539, doi: 10.1175/1520-0493(1991)119<2519: RAOATF $>2.0 . C O ; 2$. [Link]

Smith, B. L., S. E. Yuter, P. J. Neiman, and D. E. Kingsmill, 2010: Water vapor fluxes and orographic precipitation over northern California associated with a landfalling atmospheric river. Mon. Weather Rev., 138, 74-100, doi: 10.1175/2009MWR2939.1. [Link]

Tao, S. Y. and L. Chen, 1987: A review of recent research on the East Asian summer monsoon in China. In: Chang, C. P. and T. N. Krishnamurti (Eds.), Monsoon
Meteorology, Oxford University Press, New York, USA, 60-92.

Teng, J. H., C. S. Chen, T. C. C. Wang, and Y. L. Chen, 2000: Orographic effects on a squall line system over Taiwan. Mon. Weather Rev., 128, 1123-1138, doi: 10 $.1175 / 1520-0493(2000) 128<1123$ :OEOASL > 2.0.CO; 2. [Link]

Trier, S. B., D. B. Parsons, and T. J. Matejka, 1990: Observations of a subtropical cold front in a region of complex terrain. Mon. Weather Rev., 118, 2449-2470, doi: 10.1175/1520-0493(1990)118<2449:OOASCF >2.0.C O;2. [Link]

Wang, T. C. C., Y. J. Lin, H. Shen, and R. W. Pasken, 1990: Characteristics of a subtropical squall line determined from TAMEX dual-Doppler data. Part I: Kinematic structure. J. Atmos. Sci., 47, 2357-2381, doi: 10.117 5/1520-0469(1990)047<2357:COASSL>2.0.CO;2. [Link]

Zhang, Q. H., K. H. Lau, Y. H. Kuo, and S. J. Chen, 2003: A numerical study of a mesoscale convective system over the Taiwan Strait. Mon. Weather Rev., 131, 11501170, doi: 10.1175/1520-0493(2003)131<1150:ANSO$\mathrm{AM}>2.0 . \mathrm{CO}$;2. [Link] 